\title{
Social Safety Nets and Nutrient Deprivation: An Analysis of the National Rural Employment Guarantee Program and the Public Distribution System in India*
}

\author{
Raghbendra Jha, \\ Australian National \\ University
}

\author{
Sambit Bhattacharyya, \\ Australian National \\ University
}

\author{
Raghav Gaiha \\ University of Delhi
}

\begin{abstract}
Using primary data collected during 2007-08 we examine the nutritional status with respect to the two macronutrients (calories and protein) as well as various micronutrients of rural households in three Indian states: Andhra Pradesh, Maharashtra and Rajasthan. We find that, by and large, there are serious deficiencies in regard to consumption of various nutrients in all three states. With this as a background we model the impact of two policy interventions (NREG and PDS) on nutrient intake. In addition to OLS and IV estimations for each nutrient for each state, we also conduct systems estimation for each nutrient for all states. In many cases, there are significant effects of the two policy interventions on nutrient intakes. The impact effects of a change in the policy measures are also computed and found to vary across nutrients and states. Finally, in order to assess the impact on an index of undernutrition, both the nutrient-income relation and how the proportions of undernourished vary must be taken into account. As our analysis demonstrates, a preoccupation with the former could be misleading.
\end{abstract}

JEL Classification: D12, H53, O12,

Keywords: Nutrition, Social Safety Nets, NREG, PDS, India

All correspondence to:

Prof. Raghbendra Jha,

Australia South Asia Research Centre,

Research School of Pacific \& Asian Studies,

H.C. Coombs Building (09)

Australian National University,

Canberra, ACT 0200, Australia

Phone: + 6126125 2683; Fax: + 6126125 0443; Email: r.jha@anu.edu.au

\footnotetext{
* We gratefully acknowledge financial support from Australian Research Council-AusAID Linkage grant LP0775444 and helpful comments from C. Peter Timmer. We are also thankful to Raj Bhatia for his excellent statistical support and to Nitin Gupta for research assistance. The usual caveat applies.
} 


\section{Introduction}

Despite rapid economic growth in recent times the nutritional status of a vast majority of Indians has not recorded commensurate improvement. Between 1980 and 2005 real GDP per capita grew at a rate of $3.9 \%$ per annum whereas this growth between 2000 and 2005 was an even more impressive 5.4\%. Even though less spectacular, real per capita consumption growth during the 2000 and 2005 period has also been strong at 3.9\% per annum. Yet, as Deaton and Dreze (2009) indicate, more than $75 \%$ of the population has daily per capita calorie consumption below 2,100 in urban areas and 2,400 in rural areas. These magnitudes are cited as minimum requirements for Indians. ${ }^{1}$

When it comes to nutritional deprivation most attention is paid to calorie consumption. However, there are reasons to be concerned about the deprivation of the other macronutrient (protein) and various micronutrients. Apart from the consequences of such deprivation for health and well-being, there is evidence (Jha et al., 2009b) to support the contention that this deprivation is actually leading to a poverty nutrition trap where low nutrition leads to low productivity which leads to low wages which lead to low nutrition, thus completing a vicious cycle.

In view of this, it becomes important to understand the impact of various anti-poverty interventions on nutrition. This paper is addressed to this topic. We empirically model the impact of two key policy interventions (the recent National Rural Employment Guarantee Program (NREG) and the much older Public Distribution System (PDS)) in the rural sector of three states in India: Rajasthan, Maharashtra and Andhra Pradesh.

Our contribution in this paper is three fold. First, using primary data collected during 200708, we are able to examine the nutritional status of rural households in three Indian states: Andhra Pradesh, Maharashtra and Rajasthan with respect to the two macronutrients (calories and protein) as well as various micronutrients. Second, we estimate the impact of two key policy initiatives (NREG and PDS) on nutritional status of rural Indians. To the best of our knowledge, ours is the first study to examine the nutritional impact of these two policy initiatives. Third, we also report impact coefficients of a policy intervention, which in our view can serve as a useful guide for future policy on anti-poverty programs and nutrition.

\footnotetext{
${ }^{1}$ FAO (2008) has used for India a lower calorie norm of 1770 calories per day.
} 
The literature on the nutritional impact of anti-poverty programs is rather sparse. A somewhat dated but detailed analysis of the impact of the PDS on calorie intake and its costeffectiveness is Radhakrishna et al. (1997). Another notable contribution is Narayana et al. (1991) which assesses the cost-effectiveness of PDS and rural public works but stops short of analyzing their nutritional impact. Our study seeks to fill this gap.

Our study is related to a large literature on workfare programs. Much of it is, however, focused on its targeting (Besley and Coate, 1992, Ravallion and Datt, 1995, Gaiha, 2000, Jha et al. 2009a).Our study is also linked to a large literature on poverty nutrition trap. The effect of nutritional intake on labour productivity and wage rates has been an important area of research for health economists and nutritionists for some time. This found initial expression in the form of efficiency wage hypothesis developed by Leibenstein (1957) and Mazumdar (1959), and formalized and extended by Dasgupta and Ray (1986, 1987), Dasgupta (1993), Mirrlees (1975), among others. Early surveys include Bliss and Stern (1978a, 1978b) and Binswanger and Rosenzweig (1984). Jha et al (2009b) offer an empirical validation with an all-India household survey. However, the extent of the link is that policy interventions may have nutritional benefits which may lead to productivity gains and thus result in more sustained reduction in deprivation. This is particularly important as a recent report-referred to as the Tendulkar Committee report on Poverty (2009) - has sought to delink estimation of poverty from calorie norms. ${ }^{2}$ In fact, India's progress in poverty reduction leads to dramatically different conclusions depending on whether the focus is on consumption poverty or the more pervasive nutritional deprivation. ${ }^{3}$

\section{Salient Features of NREG and PDS}

National Rural Employment Guarantee Act (NREGA) came into effect in November, 2005. It was hailed as one of India's most creative social initiatives. The act guarantees 100 days of employment a year to at least one member of any rural household who is willing to perform unskilled labour for the minimum wage. By combining rural development with livelihood protection, the work is designed to develop infrastructure such as roads, and irrigation and flood protection measures. Beginning with the poorest 200 districts, NREGA became a nationwide program in April, 2008. Thus the direct transfer net of opportunity cost of time could be viewed as a conditional cash transfer.

\footnotetext{
${ }^{2}$ This committee, headed by S. Tendulkar, submitted its report to the Planning Commission on 8 December, 2009.

${ }^{3}$ For a comment along these lines, see Gaiha and Kulkarni (2009).
} 
The Public Distribution System (PDS) refers to the distribution of some essential commodities (e.g. wheat, rice, kerosene) by the government at subsidized rates through ration and fair price shops. Thus the amounts purchased multiplied by the difference between the retail and PDS prices is equivalent to a real income transfer. In recent years, attempts have been made to revamp the PDS by targeting it better on the poorest segments. Under the Antodaya in the Targeted Public Distribution System, for example, 10 million of the poorest BPL households are identified and $25 \mathrm{~kg}$ of foodgrains are given to each eligible family at a highly subsidized rate of Rs $2 \mathrm{~kg}$ of wheat and Rs 3 per $\mathrm{kg}$ of rice. ${ }^{4}$

In effect, in both cases, income transfers translate into additional nutrient intake. However, estimates of calorie-income elasticities vary over a large range (from negligible in Behrman and Deolalikar (1987) to .30 to .50 in Subramanian and Deaton (1996)). Ravallion (1990) makes an important point that, even if calorie-income elasticity is low, the effect on undernutrition may be large if the density of people is high in the neighbourhood of calorie requirement norm. More specifically, the marginal effect of a change in the incomes of undernourished households on a headcount index of undernutrition is determined by the product of the income slope of nutrient intake and the slope of the cumulative distribution function of intake, evaluated at the nutrient norm. Thus, even if calorie-income elasticities are low, there are grounds for optimism about the prospects of eliminating nutritional deprivation by raising incomes of the poor. This is broadly the perspective that informs our analysis of the nutritional impact of the NREG and PDS.

The plan of this paper is as follows. In section II, we describe the data and methodology. Section III presents and discusses the results and section IV concludes.

\section{Data and Methodology}

The present analysis draws upon primary household data drawn from three Indian states: Rajasthan, Andhra Pradesh and Maharashtra. The data were collected during 2007-08. The sample survey was designed to be a representative one for the following reasons. First, a list of NREG districts was compiled for each state. From these districts, three were selected on the basis of probability proportional to size (in this case, rural population as reported in the 2001 Census) in the case of Rajasthan. In a similar manner, six districts were selected for

\footnotetext{
${ }^{4}$ Responding to the recent surge in food prices and to lower foodgrain stocks, the allocations of wheat and rice are now larger, For details, see Gulati and Narang (2010).
} 
each of Andhra Pradesh and Maharashtra. The next step proceeded as follows. In the case of Rajasthan, for example, three villages were randomly selected from each district, followed by a random selection of households. Twenty five households were selected from each of twenty villages spread over three districts. In Andhra Pradesh and Maharashtra, these 25 villages were spread over 6 districts each. In each village 20 households were randomly selected giving us a sample of 500 households in each of the three states surveyed (see table 12). ${ }^{5}$ Apart from household level information individuals within households were also interviewed. The data include information on caste, occupation, landholdings, household size, NREG participation, type of ration card, and PDS participation. ${ }^{6}$ The number of individuals interviewed for Rajasthan, Andhra Pradesh and Maharashtra were, respectively, 2664, 2190, and 2270 .

A detailed commodity classification was used together with careful measurement of physical quantities of food items consumed. In addition, data on household expenditure on these items were canvassed. Food intake was converted into nutrients consumed using the conversion factors in Gopalan et al. (1971) - these are the most detailed and widely used conversion factors in India. The survey data collected combines a detailed classification of food commodities with a careful measurement of physical quantities consumed. The conversion of food items consumed into nutrient intakes is thus reliable.

\section{Results}

We begin by reporting some basic nutritional characteristics of the selected sample. Table 1 reports on the percentage of households that are deprived in one or more nine essential nutrients (protein, calories, calcium, iron, carotene, thiamine, riboflavin, vitamin $\mathrm{C}$, and niacin) in Andhra Pradesh whereas Table 2 reports on basic statistics on the intake of various nutrients in Andhra Pradesh.

\section{Tables 1 and 2 here.}

\footnotetext{
${ }^{5}$ The districts chosen in Rajasthan were Sirohi, Udaipur and Jhalwar. In Andhra Pradesh the six districts chosen were Karimnagar, Mahbubnagar, Nalgonda, Warangal, Vizianagaram and Chittoor. The districts selected in Maharashtra were Gondia, Chandrapur, Yavatmal, Nanded, Hingoli and Ahmednagar,

${ }^{6}$ NREG participation is measured using the question - are you a beneficiary of NREGP? PDS participation is measured using the questions - whether the household draws food grain from PDS, whether the household draws sugar from PDS, whether the household draws kerosene from PDS?
} 
Tables 3 and 4 report the corresponding statistics on Maharashtra and Tables 5 and 6 on Rajasthan.

\section{Tables 3 to 6 here}

The cutoff points for nutritional deprivation are taken from Gopalan et al. (1971) and reported in Appendix 1. In AP no household was adequately nourished in all nine categories of nutrients whereas as many as $46.1 \%$ of the population experienced deprivation in all nine nutrients. Mean consumption of all nutrients except iron was below the respective cutoff point for nutritional deprivation. However, there was considerable inequality in nutrient consumption across the sample with the minimum cutoff for calories, for example, attained only for households in the top $10 \%$ by calorie consumption.

The nutritional profile of Maharashtra is slightly better. $1.3 \%$ of the population is adequately nourished across all nine nutritional categories. $62.1 \%$ of these had household per capita income above Rs. 2400 a month. The highest incidence of deprivation occurred for all nine categories of nutrients with $32 \%$ of households deficient in all nine nutrients. Mean intake of iron was at exactly the cutoff point for deprivation in this nutritional intake whereas the mean intakes of all other nutrients were below their respective minimum cutoff points for nutritional deprivation. As in the case of AP, there was considerable inequality across households in nutritional attainment with the minimum norm for calorie intake reached only by the top $5 \%$ of households by calorie consumption.

In Rajasthan only $0.5 \%$ of households were adequately nourished across all nine nutrients. However, of the three states considered here, Rajasthan had the lowest incidence of deprivation across all nine nutrients: $29 \%$ of households. Further, mean nutritional attainment in quite a few categories was above the respective minimum cutoff values. Thus, average intake of protein, calcium, iron, thiamine and niacin were all above the respective cutoff values. However, it is also worth noting that only the median protein intake was above the minimum cutoff point for nutritional deprivation whereas median intakes for all other nutrients were below their respective cutoff values.

Against this background, it becomes imperative to assess the nutritional impact of social safety nets. In this paper we address this issue for NREG and PDS. 
We model nutritional attainment as a function of PDS participation, the NREG Wage, Non NREG Wage income and social characteristics such as religion and caste. However, PDS participation, NREG wage as well as non-NREG income may be endogenous. Hence, we conduct Instrumental Variable (IV) estimation for each nutrient for each state. Thus, for each nutrient, the equation estimated is:

$\mathrm{n}_{\mathrm{i}}=\beta_{1}$ PDSParticipation $_{\mathrm{i}}+\beta_{2}$ NREGWage $_{\mathrm{i}}+\beta_{3}$ NonwageIncome $_{\mathrm{i}}+\mathbf{X}_{\mathbf{i}} \boldsymbol{\gamma}$

where $\mathrm{n}_{\mathrm{i}}$ is intake of nutrient $n$ for household $i$ and $\mathbf{X}_{\mathrm{i}}$ is a vector of household characteristics for household $i$.

PDS participation, NREG wage and non-NREG Income are instrumented by a dummy for landownership, distance from the fair price shop, fair price shop waiting time, and religion and caste dummies. Appendix II describes the variables used in this paper.

For the abovementioned to be valid instruments, they have to satisfy the twin conditions of being correlated with the suspected endogenous variables (PDS participation, NREG wage and non-NREG Income) and orthogonal to the error term. These correlations are reported in Table 10 which reports the first stages.

The instruments also have to satisfy the exclusion restriction. In other words, they would affect nutrition only through the suspected endogenous variables and should not have any other direct or indirect effects. To check this, we also look at the direct effects of these instruments on nutrition by adding them as explanatory variables. We fail to find any evidence of direct effects. These results are not reported to save space but are available upon request.

Equation 1 is estimated for fourteen nutrients (protein, fat, minerals, carbohydrates, fiber, calories (energy), phosphorus, iron, carotene, thiamine, riboflavin, niacin and vitamin $\mathrm{C}$ ) for each state using OLS (not reported here) and IV methods. Tables 7, 8 and 9 depict IV results from rural Andhra Pradesh, Maharashtra and Rajasthan, respectively. Table 10 reports on the first stage regressions for each of these states. Note that we also subject our results to further scrutiny by omitting influential outliers from the sample using the Cook's distance, DFITS 
and Welsch distance formulas ${ }^{7}$ and our results are robust. These results are not reported here to save space but are available upon request.

\section{Tables 7, 8, 9 and 10 here}

For each of the three states we also carried out system- wide estimation for all nutrients jointly, i.e., using IV methods, we estimated (1) jointly for all nutrients. The results are very similar to the estimation of the equation for individual nutrients and are not reported here to save space.

A summary of the results for each nutrient in each state in respect of the impacts of NREG wage and PDS participation for each nutrient for all techniques of estimation (OLS, IV and system) is given in Table 11.

\section{Table 11 here}

The results are broadly similar across the three estimation techniques. Thus, across all three estimation techniques both NREG Wage and PDS Participation significantly increase the intake of protein, carbohydrates, calories, phosphorus, iron, thiamine, and niacin in AP, Maharashtra and Rajasthan. In the case of fat, NREG wage has an insignificant impact whereas PDS has a significant positive impact in AP but neither has a significant impact in the other two states. In the case of minerals, the impacts of both NREG wage and PDS participation are significant and positive in AP and Maharashtra but insignificant in Rajasthan. In AP and Rajasthan, neither NREG wage nor PDS participation has a significant impact on fiber consumption. The impacts of both on fiber consumption are positive and significant in Maharashtra. In the case of calcium consumption, in Maharashtra, both PDS participation and NREG wage have positive and significant effects whereas neither is significant in the case of Rajasthan. In AP, PDS participation has a positive and significant effect on calcium consumption but the impact of NREG wage is insignificant. In the case of carotene consumption, both NREG wage and PDS participation have significant and positive impacts in AP and Maharashtra but the impact of both is insignificant in Rajasthan. In the case of riboflavin, both NREG wage and PDS participation have positive and significant

\footnotetext{
${ }^{7}$ Cook's distance, DFITS and Welsch distance formulas suggest omit if $\mid$ Cooksd $_{i} \mid>4 / n$; omit if $\left|\operatorname{DFITS}_{i}\right|>2 \sqrt{k / n}$; and omit if $\mid$ Welschd $_{i} \mid>3 \sqrt{k}$ respectively (see Belsley et al. 1980).
}

Here $n$ is the number of observation and $k$ is the number of independent variables including the intercept. 
impacts in AP, whereas in Maharashtra PDS participation is significant but NREG wage is not. In Rajasthan, the opposite is true. Both PDS participation and NREG wage have significant and positive effects on Vitamin C consumption in AP and Maharashtra whereas neither has a significant impact in Rajasthan.

Thus, the two policy interventions have varied impacts on the intake of various nutrients in the three states studied here. This is a reflection, among other factors, of the ways in which the income from NREG and the income transfer implicit in the PDS are spent and the dietary preferences of households in the three states.

To compare the impact effect of a change in PDS participation with that of a change in PDS participation, Table 12 reports the impact coefficients of PDS participation and NREG wage on the fourteen nutrients considered in this paper. Keeping all other factors unchanged, impact coefficient of an explanatory variable is the predicted change in nutrient intake for a one standard deviation increase in that explanatory variable. For example, ceteris paribus, the impact of one standard deviation increase in PDS participation on the protein intake of an average adult in a household in Andhra Pradesh would be 3.5 grams per day. The advantage of impact coefficients is that they are comparable across explanatory variables (PDS participation and NREG wage in this case), since an equivalent change of one sample standard deviation is considered in each of the explanatory variables. ${ }^{89}$

\section{Table 12 here}

Ceteris paribus, a one standard deviation increase in participation in PDS has significant and positive impacts on all fourteen nutrients in AP and, indeed, the coefficients for increase in PDS participation are larger than those for an increase in NREG wage, many of which are insignificant. In Maharashtra, the impact on fats is insignificant in both cases and the impact of an increase in PDS participation is higher for vitamin C consumption. In all other cases, an increase in NREG wage has a larger impact on nutrient intake than an increase in PDS participation. Rajasthan presents a more complex picture. For fats, calcium, carotene, and vitamin $\mathrm{C}$ the impact effects are insignificant in both cases. For riboflavin consumption an increase in the NREG wage has a significant impact whereas the impact of an increase in

\footnotetext{
${ }^{8}$ Note that even though PDS participation is a binary variable and NREG wage is a continuous variable, their impact coefficients are comparable because they are computed using one sample standard deviation change. ${ }^{9}$ An important issue arising here is why a rupee from NREG has greater nutritional effects than the same amount from other sources. The answer may lie in the fact that since more physical work is involved in NREG and therefore energy expenditure is greater, the higher nutrient intake helps restore homeostatic equilibrium. Srinivasan (1981) states that energy intake depends on energy expenditure and thus any shortfall in the latter within a (homeostatic range) does not impair physical functioning. We are grateful to Peter Timmer for pointing this out to us.
} 
PDS participation is insignificant. For carbohydrates, calories, phosphorus, iron and niacin the impact of an increase in PDS participation is greater than that of an increase in the NREG wage. In the remaining cases the impact of an increase in NREG wage is greater.

\section{Table 13 here}

As noted earlier, and following Ravallion (1990), we report the effects of a transfer of one hundred rupees (through NREG and PDS) on the headcount index of undernutrition. ${ }^{10}$ The idea is to have (approximate) measures of slopes of nutrient-income relation at the level of income just adequate to meet the nutritional norm, ${ }^{11}$ and of the cdf at the nutrient norm. Their product yields an (approximate) measure of the change in the headcount index of undernutrition induced by a transfer of Rs. 100 of real income. Graphical representations of the nutrient-income relations and the cdfs for different nutrients, and numerical results are given. Our comments are brief and selective.

Our comments are confined to the nutrients for which the effects on the headcount index are relatively large. For calories, the effect in Andhra Pradesh is largest, followed by Maharashtra and Rajasthan. As may be noted from Table 13, the slope of the calorie-income relation more than compensates for the low slope of the cdf in terms of the effect on the headcount index in Andhra Pradesh, relative to Maharashtra. In the case of protein, Maharashtra has the largest effect mainly because the slope of the protein-income relation is the steepest. For calcium, a micronutient, the effect is largest in Rajasthan because of a combination of steep slopes of calcium-income relation and the cdf. In the case of carotene, another micronutrient, Andhra Pradesh shows the largest effect because of a combination of steep slopes of both. In the case of iron too, the largest effect on the headcount index is observed in Andhra Pradesh primarily because of the high iron-income elasticity.

\footnotetext{
${ }^{10}$ This analysis could be extended to the FGT class of undernutrition indices. For details, see Ravallion (1990).

${ }^{11}$ One may argue that the slopes of nutrient-income relation at the nutritional cut off points (reported in Appendix I and also indicated by a horizontal line in Figure 1) are influenced by the presence of outliers. We test for this by calculating the slopes in a sample without outliers and our results remain unaffected. This in our view is due to the bunching of a lot of observations around the cut off points.
} 
In sum, one hundred rupees of real income transferred through anti-poverty interventions have varying effects on the headcount indices of undernutrition in the three states in question. Nothing, however, can be said about the cost-effectiveness of such transfers, as their costs are likely to vary with the intervention and state.

\section{Conclusions}

Using primary data collected during 2007-08 this paper has examined the nutritional status with respect to the two macronutrients (calories and protein) as well as various micronutrients of rural households in three Indian states: Andhra Pradesh, Maharashtra and Rajasthan. It was found that, by and large, there are serious deficiencies in regard to consumption of various nutrients in all three states. With this as background, we modelled the impact of two policy interventions (NREG and PDS) on nutrient intake. Apart from OLS, IV estimation for each nutrient for each state and systems estimation for each nutrient for all states were conducted. In many cases, we found significant effects of the two policy interventions on nutrient intakes. The impact effects of a change in the policy measures were also computed and found to vary by nutrient and by state. Finally, in order to assess the impact on an index of undernutrition, both the nutrient-income relation and how the proportion of undernourished vary must be taken into account. As our analysis demonstrates, a preoccupation with the former could be misleading. A useful extension of the analysis, but outside the scope of this paper, would take into account the cost effectiveness of reducing undernutrition through NREG and PDS. . 


\section{References}

Behrman, J. and A. Deolalikar (1987) "Will Developing Country Nutrition Improve with Income? A Case Study for Rural South India”, Journal of Political Economy, 95, 492-507.

Belsley, D., E. Kuh, and R. Welsch. (1980). "Regressions Diagnostics: Identifying Influential Data and Sources of Collinearity," New York: John Wiley \& Sons.

Besley, T. and S. Coate (1992) "Workfare versus Welfare: Incentive Arguments for Work Requirements in Poverty-Alleviation Programs" The American Economic Review, 82(1), 249-61.

Bliss, C. and N. Stern (1978a), "Productivity, Wages and Nutrition: Part I: The Theory", Journal of Development Economics 5, 331-62

C. Bliss and N. Stern (1978b), "Productivity, Wages and Nutrition: Part II: Some Observations", Journal of Development Economics 5, 363-98.

Dasgupta, P. (1993) An Inquiry into Well-Being and Destitution, Oxford University Press, Oxford Deaton, A. and J. Dreze (2009) "Food and Nutrition in India: Facts and Interpretation" Economic and Political Weekly, XLIV(7), 42-64.

Dasgupta, P. and D. Ray(1986) "Inequality as a Determinant of Malnutrition and Unemployment: Theory", Economic Journal 96, 1011-34.

Dasgupta, P. and D. Ray (1987) "Inequality as a Determinant of Malnutrition and Unemployment: Policy", Economic Journal 97, 177-88.

Gaiha, R (2000) “Do Anti-Poverty Programs Reach the Rural Poor in India?” Oxford Development Studies 28: 1.

Gaiha, R. and Vani S. Kulkarni (2009) “Losing the War Against Poverty?”, The Economic Times, 31 December.

Gopalan C, Sastri B., Balasubramanian S. (1971) Nutritive Value of Indian Foods. National Institute of Nutrition: Indian Council of Medical Research: Hyderabad.

Greene W. (2003) Econometric Analysis: Fifth Edition. Prentice Hall: Upper Saddle River NJ.

Gulati, A., T. Narang (2010) "Higher Output Not Enough to Cool Food Prices", The Economic Times, 2 February.

Jha, R., S. Bhattacharya, R. Gaiha, and S. Shankar (2009a) "Capture” of Anti-Poverty Programs: An Analysis of the National Rural Employment Guarantee Program in India” Journal of Asian Economics, 20(4), 456-64, September 2009.

Jha, R., Gaiha, R. \& A. Sharma (2009 b) "Calorie and Micronutrient Deprivation and Poverty Nutrition Traps in Rural India” World Development, 37(5), 982-91.

Leibenstein, H. (1957), Economic Backwardness and Economic Growth: Studies in the Theory of Economic Development, Wiley \& Sons, New York.

Mazumdar, D. (1959) “The Marginal Productivity Theory of Wages and Unemployment”, Review of Economic Studies 26, 190-97.

Mirrlees, J. (1975), “A Pure Theory of Underdeveloped Economies”, in: L. Reynolds (ed.), Agriculture in Development Theory, Yale University Press, New Haven (1975), pp. 84-108

Narayana, N.S. S. \& Srinivasan, T.N., \& Parikh, Kirit S ( 1991) Agriculture, Growth, and Redistribution of Income: Policy Analysis with a General Equilibrium Model of India, North Holland: Amsterdam \& New York

Ravallion, M. (1990) “Is Undernutrition Responsive to Changes in Incomes?”, WPS 303, World Bank.

Ravallion, M. and G. Datt, 1995 "Is Targeting Through a Work Requirement Efficient? Some Evidence for Rural India", in D. Van De Walle and K. Nead (eds), Public Spending and the Poor: Theory and Evidence, The World Bank, Washington, DC (1995), pp. 413-414.

Radhakrishna,R., K. Subbarao, S. Indrakant,and C. Ravi (1997) India's Public Distribution System: A National and International Perspective, Washington DC: World Bank.

Srinivasan, T. (1981) "Malnutrition: Some Measurement and Policy Issues" Journal of Development Economics, vol.8, no.1, pp. 3-19.

Subramanian, S, and A. Deaton (1996) "The Demand for Food and Calories" The Journal of Political Economy, 104(1), 133-62.

Tendulkar Committee Report (2009) “Expert Group on Methodology for Estimation of Poverty” Planning Commission, Government of India, available at http://planningcommission.nic.in/eg poverty.htm, accessed $5^{\text {th }}$ February 2010. 


\section{Appendix I: Cutoff points for daily intakes of various nutrients}

Calories: 2800 and 2400

Proteins: 50 (grams)

Calcium: 500 (mg.)

Iron: $20(\mathrm{mg})$

Carotene: $3000(\mu \mathrm{g})$

Thiamine: 1.4 (mg.)

Riboflavin: 1.5 (mg.)

Niacin: 19 (mg.)

Vitamin C: 50 (mg.)

\section{Appendix II: Data Description}

PDS Participation: PDS participation dummy variable taking the value 1 if the household used their ration card to get cereals (rice/wheat) or pulses in the last one year, 0 otherwise.

NREG Wage: Average per capita wage earned by the household from NREG in rupees.

Non NREG Income: Average per capita non NREG income of the household.

Hindu: Dummy variable taking the value 1 if Hindu, 0 otherwise.

Muslim: Dummy variable taking the value 1 if Muslim, 0 otherwise.

Schedule Cast: Dummy variable taking the value 1 if Schedule Cast, 0 otherwise.

Schedule Tribe: Dummy variable taking the value 1 if Schedule Tribe, 0 otherwise.

OBC: Dummy variable taking the value 1 if Other Backward Castes, 0 otherwise.

Protein, Fat, Minerals, Carbohydrate, Fiber, Energy, Calcium, Phosphorus, Iron, Carotene, Thiamine, Riboflavin, Niacin, Vitamin C: All nutrient intakes are calculated as average per day per capita intakes.

Landownership: Landownership dummy variable taking the value 1 if a landowner, 0 otherwise Distance from the Fair Price Shop: Distance measured in Kilometers Fair Price Shop waiting time: Time measured in hours. 
Table 1: Extent of Undernutrition in Andhra Pradesh

\begin{tabular}{|c|c|c|c|c|c|c|c|c|}
\hline \multicolumn{9}{|c|}{ Household Income Rupees per capita per month } \\
\hline $\begin{array}{l}\text { Number of } \\
\text { nutrients } \\
\text { deficient in }\end{array}$ & $0-400$ & $400-800$ & $800-1200$ & $1200-1600$ & $1600-2000$ & $2000-2400$ & $>2400$ & Total \\
\hline 1 & $0.0 \%$ & $0.0 \%$ & $1.1 \%$ & $9.2 \%$ & $0.0 \%$ & $0.0 \%$ & $15.0 \%$ & $1.5 \%$ \\
\hline 2 & $0.0 \%$ & $0.5 \%$ & $8.5 \%$ & $0.0 \%$ & $44.4 \%$ & $0.0 \%$ & $3.5 \%$ & $3.1 \%$ \\
\hline 3 & $6.9 \%$ & $0.0 \%$ & $10.6 \%$ & $20.4 \%$ & $41.4 \%$ & $26.0 \%$ & $39.4 \%$ & $7.3 \%$ \\
\hline 4 & $0.0 \%$ & $5.5 \%$ & $7.3 \%$ & $9.3 \%$ & $10.4 \%$ & $0.0 \%$ & $2.4 \%$ & $5.6 \%$ \\
\hline 5 & $0.0 \%$ & $5.1 \%$ & $9.2 \%$ & $4.3 \%$ & $1.9 \%$ & $0.0 \%$ & $0.0 \%$ & $5.1 \%$ \\
\hline 6 & $8.3 \%$ & $6.3 \%$ & $7.3 \%$ & $17.5 \%$ & $0.0 \%$ & $0.0 \%$ & $30.6 \%$ & $8.3 \%$ \\
\hline 7 & $5.6 \%$ & $7.6 \%$ & $9.4 \%$ & $12.5 \%$ & $1.9 \%$ & $8.9 \%$ & $6.5 \%$ & $8.1 \%$ \\
\hline 8 & $11.8 \%$ & $17.7 \%$ & $14.5 \%$ & $6.5 \%$ & $0.0 \%$ & $48.5 \%$ & $2.6 \%$ & $14.9 \%$ \\
\hline 9 & $67.4 \%$ & $57.4 \%$ & $31.9 \%$ & $20.2 \%$ & $0.0 \%$ & $16.5 \%$ & $0.0 \%$ & $46.1 \%$ \\
\hline Total & $100.0 \%$ & $100.0 \%$ & $100.0 \%$ & $100.0 \%$ & $100.0 \%$ & $100.0 \%$ & $100.0 \%$ & $100.0 \%$ \\
\hline \multicolumn{9}{|c|}{ Household Income Rupees per capita per month } \\
\hline $\begin{array}{l}\text { Number of } \\
\text { nutrients } \\
\text { deficient in }\end{array}$ & $0-400$ & $400-800$ & $800-1200$ & $1200-1600$ & $1600-2000$ & $2000-2400$ & $>2400$ & Total \\
\hline 1 & $0.0 \%$ & $0.0 \%$ & $15.8 \%$ & $52.7 \%$ & $0.0 \%$ & $0.0 \%$ & $31.5 \%$ & $100.0 \%$ \\
\hline 2 & $0.0 \%$ & $7.8 \%$ & $60.6 \%$ & $0.0 \%$ & $28.0 \%$ & $0.0 \%$ & $3.6 \%$ & $100.0 \%$ \\
\hline 3 & $10.4 \%$ & $0.0 \%$ & $32.1 \%$ & $24.5 \%$ & $11.1 \%$ & $4.5 \%$ & $17.4 \%$ & $100.0 \%$ \\
\hline 4 & $0.0 \%$ & $51.3 \%$ & $28.9 \%$ & $14.7 \%$ & $3.7 \%$ & $0.0 \%$ & $1.4 \%$ & $100.0 \%$ \\
\hline 5 & $0.0 \%$ & $51.7 \%$ & $40.0 \%$ & $7.5 \%$ & $0.7 \%$ & $0.0 \%$ & $0.0 \%$ & $100.0 \%$ \\
\hline 6 & $11.0 \%$ & $39.1 \%$ & $19.5 \%$ & $18.5 \%$ & $0.0 \%$ & $0.0 \%$ & $11.9 \%$ & $100.0 \%$ \\
\hline 7 & $7.5 \%$ & $48.5 \%$ & $25.8 \%$ & $13.7 \%$ & $0.5 \%$ & $1.4 \%$ & $2.6 \%$ & $100.0 \%$ \\
\hline 8 & $8.7 \%$ & $61.4 \%$ & $21.4 \%$ & $3.8 \%$ & $0.0 \%$ & $4.1 \%$ & $0.6 \%$ & $100.0 \%$ \\
\hline 9 & $16.0 \%$ & $64.5 \%$ & $15.2 \%$ & $3.9 \%$ & $0.0 \%$ & $0.5 \%$ & $0.0 \%$ & $100.0 \%$ \\
\hline Total & $11.0 \%$ & $51.8 \%$ & $22.0 \%$ & $8.8 \%$ & $2.0 \%$ & $1.3 \%$ & $3.2 \%$ & $100.0 \%$ \\
\hline
\end{tabular}

Table 2: Descriptive Statistics for Intake of Key Nutrients (Nutrient values in per capita terms) Andhra Pradesh

\begin{tabular}{|c|c|c|c|c|c|c|c|c|c|c|c|}
\hline \multicolumn{12}{|c|}{ Descriptive Statistics for Intake of Various Nutrients (Nutrient values in per capita terms) } \\
\hline Variable & mean & sd & $\max$ & $\min$ & PG0 & PG1 & PG2 & Gini & p75 & p90 & p99 \\
\hline Protein & 41 & 14 & 111 & 16 & 0.796 & 0.236 & 0.088 & 0.189 & 47 & 59 & 88 \\
\hline Calories & 1,749 & 565 & 4,493 & 644 & $\begin{array}{c}0.954 \\
(0.876)\end{array}$ & $\begin{array}{c}0.383 \\
(0.293)\end{array}$ & $\begin{array}{c}0.180 \\
(0.122)\end{array}$ & 0.184 & 2,081 & 2,509 & 3,473 \\
\hline Calcium & 335 & 205 & 1,399 & 70 & 0.836 & 0.398 & 0.220 & 0.309 & 393 & 587 & 1,132 \\
\hline Iron & 21 & 7 & 51 & 7 & 0.550 & 0.118 & 0.035 & 0.190 & 24 & 30 & 43 \\
\hline Carotene & 1,214 & 560 & 3,773 & 180 & 0.988 & 0.596 & 0.389 & 0.245 & 1,474 & 1,884 & 3,127 \\
\hline Thiamine & 1 & 0 & 3 & 0 & 0.834 & 0.260 & 0.102 & 0.193 & 1 & 2 & 2 \\
\hline Riboflavin & 1 & 0 & 1 & 0 & 1.000 & 0.657 & 0.449 & 0.205 & 1 & 1 & 1 \\
\hline Vitamin C & 39 & 19 & 132 & 3 & 0.800 & 0.306 & 0.143 & 0.259 & 46 & 63 & 106 \\
\hline Niacin & 16 & 6 & 38 & 5 & 0.718 & 0.221 & 0.087 & 0.2079 & 20 & 24 & 36 \\
\hline
\end{tabular}

N.B. Figures in (.) indicate PG0, PG1, PG2 using 2400 as cutoff for calories. 
Social Safety Nets and Nutrient Deprivation

Table 3: Extent of Undernutrition in Maharashtra

Household Income Rupees per capita per month

\begin{tabular}{|c|c|c|c|c|c|c|c|c|}
\hline $\begin{array}{l}\text { Number of } \\
\text { nutrients } \\
\text { deficient in }\end{array}$ & $0-400$ & $400-800$ & $800-1200$ & $1200-1600$ & $1600-2000$ & $2000-2400$ & $>2400$ & Total \\
\hline 0 & $0.0 \%$ & $0.2 \%$ & $3.7 \%$ & $0.0 \%$ & $0.0 \%$ & $0.0 \%$ & $65.6 \%$ & $1.3 \%$ \\
\hline 1 & $0.0 \%$ & $0.2 \%$ & $2.5 \%$ & $15.6 \%$ & $0.0 \%$ & $0.0 \%$ & $0.0 \%$ & $0.5 \%$ \\
\hline 2 & $0.0 \%$ & $0.7 \%$ & $9.1 \%$ & $1.1 \%$ & $0.0 \%$ & $0.0 \%$ & $7.7 \%$ & $1.5 \%$ \\
\hline 3 & $0.7 \%$ & $2.5 \%$ & $21.8 \%$ & $1.1 \%$ & $34.5 \%$ & $0.0 \%$ & $0.0 \%$ & $4.4 \%$ \\
\hline 4 & $4.6 \%$ & $10.0 \%$ & $28.3 \%$ & $27.4 \%$ & $32.7 \%$ & $0.0 \%$ & $0.0 \%$ & $11.3 \%$ \\
\hline 5 & $1.8 \%$ & $8.7 \%$ & $11.8 \%$ & $37.7 \%$ & $0.0 \%$ & $0.0 \%$ & $0.0 \%$ & $8.1 \%$ \\
\hline 6 & $0.6 \%$ & $9.6 \%$ & $0.9 \%$ & $0.0 \%$ & $32.7 \%$ & $50.0 \%$ & $0.0 \%$ & $7.5 \%$ \\
\hline 7 & $8.2 \%$ & $14.2 \%$ & $2.0 \%$ & $0.0 \%$ & $0.0 \%$ & $0.0 \%$ & $0.0 \%$ & $11.6 \%$ \\
\hline 8 & $13.8 \%$ & $25.8 \%$ & $7.0 \%$ & $17.2 \%$ & $0.0 \%$ & $50.0 \%$ & $26.7 \%$ & $21.9 \%$ \\
\hline 9 & $70.2 \%$ & $28.2 \%$ & $13.0 \%$ & $0.0 \%$ & $0.0 \%$ & $0.0 \%$ & $0.0 \%$ & $32.0 \%$ \\
\hline Total & $100.0 \%$ & $100.0 \%$ & $100.0 \%$ & $100.0 \%$ & $100.0 \%$ & $100.0 \%$ & $100.0 \%$ & $100.0 \%$ \\
\hline \multicolumn{9}{|c|}{ Household Income Rupees per capita per month } \\
\hline $\begin{array}{l}\text { Number of } \\
\text { nutrients } \\
\text { deficient in }\end{array}$ & $0-400$ & $400-800$ & $800-1200$ & $1200-1600$ & $1600-2000$ & $2000-2400$ & $>2400$ & Total \\
\hline 0 & $0.0 \%$ & $8.8 \%$ & $29.2 \%$ & $0.0 \%$ & $0.0 \%$ & $0.0 \%$ & $62.1 \%$ & $100.0 \%$ \\
\hline 1 & $0.0 \%$ & $20.3 \%$ & $45.8 \%$ & $33.9 \%$ & $0.0 \%$ & $0.0 \%$ & $0.0 \%$ & $100.0 \%$ \\
\hline 2 & $0.0 \%$ & $33.7 \%$ & $59.4 \%$ & $0.9 \%$ & $0.0 \%$ & $0.0 \%$ & $6.0 \%$ & $100.0 \%$ \\
\hline 3 & $2.5 \%$ & $40.5 \%$ & $49.6 \%$ & $0.3 \%$ & $7.1 \%$ & $0.0 \%$ & $0.0 \%$ & $100.0 \%$ \\
\hline 4 & $6.2 \%$ & $63.4 \%$ & $25.0 \%$ & $2.9 \%$ & $2.6 \%$ & $0.0 \%$ & $0.0 \%$ & $100.0 \%$ \\
\hline 5 & $3.3 \%$ & $76.6 \%$ & $14.6 \%$ & $5.5 \%$ & $0.0 \%$ & $0.0 \%$ & $0.0 \%$ & $100.0 \%$ \\
\hline 6 & $1.3 \%$ & $90.6 \%$ & $1.2 \%$ & $0.0 \%$ & $3.9 \%$ & $3.1 \%$ & $0.0 \%$ & $100.0 \%$ \\
\hline 7 & $10.7 \%$ & $87.5 \%$ & $1.8 \%$ & $0.0 \%$ & $0.0 \%$ & $0.0 \%$ & $0.0 \%$ & $100.0 \%$ \\
\hline 8 & $9.5 \%$ & $83.9 \%$ & $3.2 \%$ & $0.9 \%$ & $0.0 \%$ & $1.1 \%$ & $1.4 \%$ & $100.0 \%$ \\
\hline 9 & $33.2 \%$ & $62.8 \%$ & $4.0 \%$ & $0.0 \%$ & $0.0 \%$ & $0.0 \%$ & $0.0 \%$ & $100.0 \%$ \\
\hline Total & $15.1 \%$ & $71.2 \%$ & $9.9 \%$ & $1.2 \%$ & $0.9 \%$ & $0.5 \%$ & $1.2 \%$ & $100.0 \%$ \\
\hline
\end{tabular}

Table 4: Descriptive Statistics for Intake of Key Nutrients (Nutrient values in per capita terms) Maharashtra

\begin{tabular}{|c|c|c|c|c|c|c|c|c|c|c|c|}
\hline & mean & sd & $\operatorname{Max}$ & $\min$ & PGO & PG1 & PG2 & Gini & p75 & p9o & p99 \\
\hline Protein & 44 & 14 & 174 & 21 & 0.762 & 0.17339 & 0.0543 & 0.1682 & 50 & 60 & 92 \\
\hline Calories & 1,672 & 503 & 6,398 & 764 & $\begin{array}{c}0.976 \\
(0.944)\end{array}$ & $\begin{array}{c}0.409 \\
(0.317)\end{array}$ & $\begin{array}{c}0.190 \\
(0.127)\end{array}$ & 0.1574 & 1,912 & 2,210 & 3,154 \\
\hline Calcium & 542 & 223 & 1,819 & 73 & 0.500 & 0.120 & 0.041 & 0.2191 & 648 & 822 & 1,225 \\
\hline Iron & 20 & 6 & 74 & 7 & 0.564 & 0.107 & 0.031 & 0.1628 & 23 & 27 & 39 \\
\hline Carotene & 1,553 & 717 & 4,888 & 290 & 0.956 & 0.491 & 0.287 & 0.2376 & 1,883 & 2,571 & 3,936 \\
\hline Thiamine & 1 & 0 & 5 & 1 & 0.634 & 0.137 & 0.042 & 0.1779 & 2 & 2 & 3 \\
\hline Riboflavin & 1 & 0 & 3 & 0 & 0.984 & 0.517 & 0.291 & 0.1923 & 1 & 1 & 2 \\
\hline Vitamin C & 45 & 21 & 150 & 9 & 0.704 & 0.228 & 0.095 & 0.2404 & 54 & 73 & 112 \\
\hline Niacin & 16 & 6 & 55 & 6 & 0.7880 & 0.2321 & 0.0880 & 0.1895 & 18 & 22 & 33 \\
\hline
\end{tabular}

N.B. Figures in (.) indicate PG0, PG1, PG2 using 2400 as cutoff for calories. 
Table 5: Extent of Undernutrition in Rajasthan

\begin{tabular}{|c|c|c|c|c|c|c|c|}
\hline \multicolumn{8}{|c|}{ Household Income Rupees per capita per month } \\
\hline $\begin{array}{l}\text { Number of } \\
\text { nutrients } \\
\text { deficient in }\end{array}$ & $0-400$ & $400-800$ & $800-1200$ & $1200-1600$ & $2000-2400$ & $>2400$ & Total \\
\hline 0 & $0.0 \%$ & $0.0 \%$ & $4.5 \%$ & $0.0 \%$ & $0.0 \%$ & $0.0 \%$ & $0.5 \%$ \\
\hline 1 & $0.0 \%$ & $0.1 \%$ & $5.8 \%$ & $5.9 \%$ & $0.0 \%$ & $0.0 \%$ & $1.0 \%$ \\
\hline 2 & $0.0 \%$ & $0.4 \%$ & $6.4 \%$ & $21.4 \%$ & $0.0 \%$ & $0.0 \%$ & $2.0 \%$ \\
\hline 3 & $2.0 \%$ & $5.0 \%$ & $23.5 \%$ & $22.1 \%$ & $0.0 \%$ & $5.9 \%$ & $7.0 \%$ \\
\hline 4 & $4.5 \%$ & $32.7 \%$ & $35.7 \%$ & $2.0 \%$ & $0.0 \%$ & $0.0 \%$ & $21.9 \%$ \\
\hline 5 & $4.5 \%$ & $12.8 \%$ & $7.1 \%$ & $0.0 \%$ & $0.0 \%$ & $0.0 \%$ & $8.6 \%$ \\
\hline 6 & $1.8 \%$ & $6.0 \%$ & $6.3 \%$ & $42.3 \%$ & $0.0 \%$ & $6.4 \%$ & $6.6 \%$ \\
\hline 7 & $4.7 \%$ & $11.7 \%$ & $2.7 \%$ & $6.2 \%$ & $0.0 \%$ & $87.7 \%$ & $8.9 \%$ \\
\hline 8 & $15.0 \%$ & $18.5 \%$ & $1.4 \%$ & $0.0 \%$ & $0.0 \%$ & $0.0 \%$ & $14.3 \%$ \\
\hline 9 & $67.5 \%$ & $12.8 \%$ & $6.6 \%$ & $0.0 \%$ & $100.0 \%$ & $0.0 \%$ & $29.0 \%$ \\
\hline Total & $100.0 \%$ & $100.0 \%$ & $100.0 \%$ & $100.0 \%$ & $100.0 \%$ & $100.0 \%$ & $100.0 \%$ \\
\hline \multicolumn{8}{|c|}{ Household Income Rupees per capita per month } \\
\hline $\begin{array}{l}\text { Number of } \\
\text { nutrients } \\
\text { deficient in }\end{array}$ & $0-400$ & $400-800$ & $800-1200$ & $1200-1600$ & $2000-2400$ & $>2400$ & Total \\
\hline 0 & $0.0 \%$ & $0.0 \%$ & $100.0 \%$ & $0.0 \%$ & $0.0 \%$ & $0.0 \%$ & $100.0 \%$ \\
\hline 1 & $0.0 \%$ & $6.0 \%$ & $63.2 \%$ & $30.7 \%$ & $0.0 \%$ & $0.0 \%$ & $100.0 \%$ \\
\hline 2 & $0.0 \%$ & $8.8 \%$ & $35.3 \%$ & $55.9 \%$ & $0.0 \%$ & $0.0 \%$ & $100.0 \%$ \\
\hline 3 & $9.4 \%$ & $35.9 \%$ & $37.2 \%$ & $16.7 \%$ & $0.0 \%$ & $0.9 \%$ & $100.0 \%$ \\
\hline 4 & $6.7 \%$ & $74.7 \%$ & $18.2 \%$ & $0.5 \%$ & $0.0 \%$ & $0.0 \%$ & $100.0 \%$ \\
\hline 5 & $16.8 \%$ & $74.1 \%$ & $9.2 \%$ & $0.0 \%$ & $0.0 \%$ & $0.0 \%$ & $100.0 \%$ \\
\hline 6 & $8.6 \%$ & $45.7 \%$ & $10.6 \%$ & $34.0 \%$ & $0.0 \%$ & $1.0 \%$ & $100.0 \%$ \\
\hline 7 & $17.2 \%$ & $65.4 \%$ & $3.4 \%$ & $3.7 \%$ & $0.0 \%$ & $10.3 \%$ & $100.0 \%$ \\
\hline 8 & $34.0 \%$ & $64.9 \%$ & $1.1 \%$ & $0.0 \%$ & $0.0 \%$ & $0.0 \%$ & $100.0 \%$ \\
\hline 9 & $75.3 \%$ & $22.1 \%$ & $2.5 \%$ & $0.0 \%$ & $0.1 \%$ & $0.0 \%$ & $100.0 \%$ \\
\hline Total & $32.4 \%$ & $50.1 \%$ & $11.2 \%$ & $5.3 \%$ & $0.0 \%$ & $1.0 \%$ & $100.0 \%$ \\
\hline
\end{tabular}


Table 6: Descriptive Statistics for Intake of Key Nutrients (Nutrient values in per capita terms): Rajasthan

\begin{tabular}{|c|c|c|c|c|c|c|c|c|c|c|c|c|}
\hline \multicolumn{1}{|c|}{ Descriptive Statistics for Intake of Various Nutrients (Nutrient values in per capita terms) } \\
\hline variable & mean & sd & max & min & PG0 & PG1 & PG2 & Gini & p75 & p90 & p99 \\
\hline \multicolumn{10}{|c|}{} \\
\hline Protein & 52.569 & 19.389 & 132.232 & 10.639 & 0.484 & 0.126 & 0.045 & 0.205934 & 63.514 & 77.806 & 113.738 \\
\hline Calories & 1722.4 & 618.811 & 4162.706 & 385.983 & $\begin{array}{c}0.958 \\
(0.872)\end{array}$ & $\begin{array}{c}0.393 \\
(0.305)\end{array}$ & $\begin{array}{c}0.195 \\
(0.138)\end{array}$ & 0.201795 & 2098.175 & 2545.609 & 3568.051 \\
\hline Calcium & 528.7 & 252.782 & 1512.008 & 110.439 & 0.524 & 0.167 & 0.074 & 0.270183 & 665.845 & 875.375 & 1287.661 \\
\hline Iron & 20.243 & 7.757 & 51.910 & 4.826 & 0.528 & 0.149 & 0.059 & 0.210879 & 25.056 & 30.760 & 41.932 \\
\hline Carotene & 1121.0 & 510.251 & 3595.593 & 135.809 & 0.996 & 0.627 & 0.421 & 0.251957 & 1393.111 & 1712.540 & 2805.672 \\
\hline Thiamine & 1.818 & 0.696 & 4.614 & 0.356 & 0.304 & 0.066 & 0.022 & 0.211579 & 2.211 & 2.730 & 4.037 \\
\hline Riboflavin & 0.870 & 0.342 & 2.782 & 0.167 & 0.96 & 0.428 & 0.225 & 0.222794 & 1.055 & 1.281 & 1.953 \\
\hline Vitamin C & 27.797 & 14.750 & 89.872 & 0.024 & 0.916 & 0.463 & 0.277 & 0.286033 & 35.464 & 47.961 & 72.990 \\
\hline Niacin & 19.525 & 7.743 & 52.598 & 3.432 & 0.52 & 0.149 & 0.06 & 0.218429 & 24.437 & 29.825 & 42.165 \\
\hline
\end{tabular}


Table 7: Anti-Poverty Programs and Nutrient Deprivation: Evidence from Rural Andhra Pradesh

\begin{tabular}{|c|c|c|c|c|c|c|c|c|c|c|c|c|c|c|}
\hline & Protein & Fat & Minerals & Carb. & Fiber & Energy & Calcium & $\begin{array}{c}\text { Phospho } \\
\text { rus }\end{array}$ & Iron & Carotene & Thiamine & Riboflavin & Niacin & Vit. C \\
\hline & \multicolumn{14}{|c|}{ IV Estimates } \\
\hline & (1) & (2) & (3) & (4) & (5) & (6) & (7) & (8) & (9) & (10) & (11) & (12) & (13) & (14) \\
\hline PDS Participation & $\begin{array}{l}15.4^{\star \star \star} \\
(2.24)\end{array}$ & $\begin{array}{l}11.5^{\star \star \star} \\
(3.06)\end{array}$ & $\begin{array}{l}1.9^{\star \star \star} \\
(0.41)\end{array}$ & $\begin{array}{c}117.7^{\star \star \star} \\
(23.6)\end{array}$ & $\begin{array}{c}0.99 \\
(0.83)\end{array}$ & $\begin{array}{l}638^{\star \star \star} \\
(110)\end{array}$ & $\begin{array}{c}90^{\star} \\
(47.9)\end{array}$ & $\begin{array}{l}299^{\star \star *} \\
(55.04)\end{array}$ & $\begin{array}{c}7^{\star \star \star} \\
(1.25)\end{array}$ & $\begin{array}{l}314^{\star \star \star} \\
(70.8)\end{array}$ & $\begin{array}{l}0.36^{\star *} \\
(0.07)\end{array}$ & $\begin{array}{l}0.16^{\star \star \star} \\
(0.03)\end{array}$ & $\begin{array}{l}5.9^{\star \star \star} \\
(1.4)\end{array}$ & $\begin{array}{l}8.8^{\star \star \star} \\
(2.9)\end{array}$ \\
\hline NREG Wage & $\begin{array}{l}0.001^{\star \star} \\
(0.0003)\end{array}$ & $\begin{array}{l}1.8 \times 10^{-6} \\
(0.0002)\end{array}$ & $\begin{array}{c}0.0001^{*} \\
(0.00004)\end{array}$ & $\begin{array}{l}0.004^{\star *} \\
(0.002)\end{array}$ & $\begin{array}{c}0.0001 \\
\left(8 \times 10^{-5}\right)\end{array}$ & $\begin{array}{l}0.02^{\star \star} \\
(0.01)\end{array}$ & $\begin{array}{l}-0.001 \\
(0.004)\end{array}$ & $\begin{array}{c}0.01^{\star} \\
(0.005)\end{array}$ & $\begin{array}{l}0.0002^{\star} \\
(0.0001)\end{array}$ & $\begin{array}{l}-0.002 \\
(0.01)\end{array}$ & $\begin{array}{l}2 \times 10^{5 * *} \\
\left(7 \times 10^{-6)}\right.\end{array}$ & $\begin{array}{c}3 \times 10^{6} \\
\left(4 \times 10^{-6}\right)\end{array}$ & $\begin{array}{l}0.0003^{\star} \\
(0.0001)\end{array}$ & $\begin{array}{c}0.0003 \\
(0.0004)\end{array}$ \\
\hline Non NREG Income & $\begin{array}{l}0.0001^{\star \star \star} \\
(0.00004)\end{array}$ & $\begin{array}{l}0.0002^{\star \star \star} \\
(0.00004)\end{array}$ & $\begin{array}{l}3 \times 10^{-5 \times \star \star} \\
\left(7.8 \times 10^{-6}\right)\end{array}$ & $\begin{array}{c}0.0004 \\
(0.0003)\end{array}$ & $\begin{array}{l}5 \times 10^{-5 * \star \star} \\
\left(5 \times 10^{-5}\right)\end{array}$ & $\begin{array}{l}0.004^{\star *} \\
(0.001)\end{array}$ & $\begin{array}{l}0.004^{\star \star} \\
(0.001)\end{array}$ & $\begin{array}{l}0.003^{\star \star} \\
(0.0008)\end{array}$ & $\begin{array}{l}4 \times 10^{-5 *} \\
\left(2 \times 10^{5}\right)\end{array}$ & $\begin{array}{l}0.01^{\star \star \star} \\
(0.002)\end{array}$ & $\begin{array}{c}3 \times 10^{-6 * k *} \\
\left(1 \times 10^{-6}\right)\end{array}$ & $\begin{array}{l}3 \times 10^{-6 \star \star \star} \\
\left(6 \times 10^{-7}\right)\end{array}$ & $\begin{array}{l}0.0001^{*} \\
\left(2 \times 10^{-5}\right)\end{array}$ & $\begin{array}{l}0.0002^{\star \star} \\
(0.00006)\end{array}$ \\
\hline Hindu & $\begin{array}{l}6.61^{\star \star \star} \\
(1.398)\end{array}$ & $\begin{array}{c}6.28 \\
(4.37)\end{array}$ & $\begin{array}{l}1.1^{\star \star \star} \\
(0.26)\end{array}$ & $\begin{array}{l}74.6^{\star * *} \\
(26.8)\end{array}$ & $\begin{array}{l}1.9^{\star \star \star \star} \\
(0.53)\end{array}$ & $\begin{array}{l}388^{\star \star \star} \\
(80.6)\end{array}$ & $\begin{array}{c}95.5 \\
(71.3)\end{array}$ & $\begin{array}{l}167^{\star \star \star} \\
(26.3)\end{array}$ & $\begin{array}{l}4.9^{\star \star \star} \\
(1.23)\end{array}$ & $\begin{array}{l}344^{\star \star \star} \\
(44.2)\end{array}$ & $\begin{array}{l}0.22^{\star \star \star} \\
(0.06)\end{array}$ & $\begin{array}{c}0.03 \\
(0.08)\end{array}$ & $\begin{array}{l}4.3^{\star \star \star} \\
(1.1)\end{array}$ & $\begin{array}{l}11^{\star \star \star} \\
(2.7)\end{array}$ \\
\hline Muslim & $\begin{array}{c}5.38 \\
(4.77)\end{array}$ & $\begin{array}{c}5.74 \\
(5.51)\end{array}$ & $\begin{array}{c}0.82 \\
(0.64)\end{array}$ & $\begin{array}{c}34.89 \\
(42.02)\end{array}$ & $\begin{array}{c}0.78 \\
(0.54)\end{array}$ & $\begin{array}{c}219.3 \\
(194.6)\end{array}$ & $\begin{array}{c}146 \\
(90.7)\end{array}$ & $\begin{array}{l}132.1 \\
(98.9)\end{array}$ & $\begin{array}{c}2.4 \\
(2.25)\end{array}$ & $\begin{array}{l}314^{\star \star} \\
(153.1)\end{array}$ & $\begin{array}{c}0.12 \\
(0.12)\end{array}$ & $\begin{array}{c}0.02 \\
(0.10)\end{array}$ & $\begin{array}{c}1.8 \\
(1.9)\end{array}$ & $\begin{array}{l}11.1^{\star \star} \\
(5.2)\end{array}$ \\
\hline SC & $\begin{array}{c}3.7 \\
(2.45)\end{array}$ & $\begin{array}{l}-1.02 \\
(2.54)\end{array}$ & $\begin{array}{c}0.38 \\
(0.38)\end{array}$ & $\begin{array}{c}27.7 \\
(17.94)\end{array}$ & $\begin{array}{c}0.03 \\
(0.63)\end{array}$ & $\begin{array}{c}116.9 \\
(100.3)\end{array}$ & $\begin{array}{c}15.8 \\
(32.3)\end{array}$ & $\begin{array}{c}66.7 \\
(50.8)\end{array}$ & $\begin{array}{c}1.26 \\
(1.15)\end{array}$ & $\begin{array}{r}38.5 \\
(84.7)\end{array}$ & $\begin{array}{c}0.08 \\
(0.07)\end{array}$ & $\begin{array}{c}0.02 \\
(0.03)\end{array}$ & $\begin{array}{c}1.1 \\
(0.9)\end{array}$ & $\begin{array}{c}2.4 \\
(2.8)\end{array}$ \\
\hline ST & $\begin{array}{c}4.24 \\
(2.68)\end{array}$ & $\begin{array}{c}0.95 \\
(2.82)\end{array}$ & $\begin{array}{c}0.57 \\
(0.41)\end{array}$ & $\begin{array}{l}45.4^{\star \star} \\
(20.8)\end{array}$ & $\begin{array}{c}0.70 \\
(0.67)\end{array}$ & $\begin{array}{l}208.1^{*} \\
(113.8)\end{array}$ & $\begin{array}{c}9.9 \\
(33.6)\end{array}$ & $\begin{array}{c}89.6 \\
(55.1)\end{array}$ & $\begin{array}{l}2.7^{\star \star} \\
(1.32)\end{array}$ & $\begin{array}{c}133 \\
(100.7)\end{array}$ & $\begin{array}{c}0.11 \\
(0.07)\end{array}$ & $\begin{array}{c}0.03 \\
(0.04)\end{array}$ & $\begin{array}{l}2.2^{\star \star} \\
(1.1)\end{array}$ & $\begin{array}{c}5.4 \\
(3.3)\end{array}$ \\
\hline OBC & $\begin{array}{c}2.21 \\
(2.26)\end{array}$ & $\begin{array}{c}0.20 \\
(2.34)\end{array}$ & $\begin{array}{c}0.18 \\
(0.35)\end{array}$ & $\begin{array}{c}20.6 \\
(16.8)\end{array}$ & $\begin{array}{l}-0.29 \\
(0.55)\end{array}$ & $\begin{array}{c}94.1 \\
(93.4)\end{array}$ & $\begin{array}{l}19.5 \\
(28.8)\end{array}$ & $\begin{array}{c}43 \\
(46.19)\end{array}$ & $\begin{array}{c}0.84 \\
(1.05)\end{array}$ & $\begin{array}{c}36.7 \\
(76.8)\end{array}$ & $\begin{array}{c}0.04 \\
(0.06)\end{array}$ & $\begin{array}{c}0.0002 \\
(0.03)\end{array}$ & $\begin{array}{c}0.8 \\
(0.9)\end{array}$ & $\begin{array}{c}1.3 \\
(2.6)\end{array}$ \\
\hline Instruments & \multicolumn{14}{|c|}{ Landownership, Distance from the Fair Price Shop, Fair Price Shop waiting time } \\
\hline Observations & 464 & 464 & 464 & 464 & 464 & 464 & 464 & 464 & 464 & 464 & 464 & 464 & 464 & 464 \\
\hline Endog. test $(p-v a l u e)$ & 0.06 & 0.09 & 0.07 & 0.07 & 0.04 & 0.001 & 0.02 & 0.06 & 0.06 & 0.03 & 0.06 & 0.06 & 0.07 & 0.04 \\
\hline Partial $R^{2}$ on instruments & 0.004 & 0.004 & 0.004 & 0.004 & 0.004 & 0.004 & 0.004 & 0.004 & 0.004 & 0.004 & 0.004 & 0.004 & 0.004 & 0.004 \\
\hline
\end{tabular}

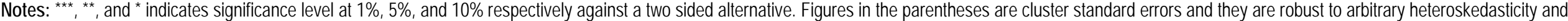

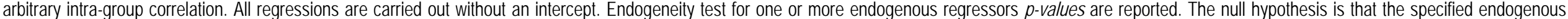

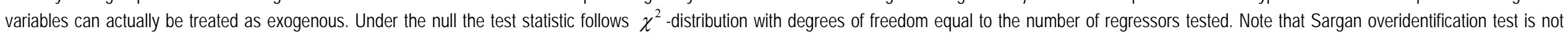
reported as the number of instruments is equal to the number of suspected endogenous variables. Partial $\mathrm{R}^{2}$ on excluded instruments are also reported which measures instrument relevance. 
Table 8: Anti-Poverty Programs and Nutrient Deprivation: Evidence from Rural Maharashtra

\begin{tabular}{|c|c|c|c|c|c|c|c|c|c|c|c|c|c|c|}
\hline & Protein & Fat & Minerals & Carb. & Fiber & Energy & Calcium & $\begin{array}{c}\text { Phospho } \\
\text { rus }\end{array}$ & Iron & Carotene & Thiamine & Riboflavin & Niacin & Vit. C \\
\hline & \multicolumn{14}{|c|}{ IV Estimates } \\
\hline & (1) & (2) & (3) & (4) & (5) & (6) & $(7)$ & (8) & (9) & (10) & (11) & (12) & (13) & (14) \\
\hline PDS Participation & $\begin{array}{c}13.2^{\star \star \star} \\
(4.6)\end{array}$ & $\begin{array}{c}1.9 \\
(7.1)\end{array}$ & $\begin{array}{l}2.4^{\star \star \star} \\
(0.75)\end{array}$ & $\begin{array}{l}71.3^{\star \star} \\
(33.3)\end{array}$ & $\begin{array}{l}2.9^{\star \star \star \star} \\
(0.78)\end{array}$ & $\begin{array}{l}347^{\star \star} \\
(172)\end{array}$ & $\begin{array}{l}188^{\star \star} \\
(90.3)\end{array}$ & $\begin{array}{l}290^{\star \star \star} \\
(109.8)\end{array}$ & $\begin{array}{l}8.6^{\star \star *} \\
(1.9)\end{array}$ & $\begin{array}{l}154^{\star \star \star} \\
(27)\end{array}$ & $\begin{array}{l}0.45^{\star \star \star \star} \\
(0.14)\end{array}$ & $\begin{array}{l}0.17^{\star} \\
(0.10)\end{array}$ & $\begin{array}{l}3.6^{\star} \\
(1.9)\end{array}$ & $\begin{array}{l}41^{\star \star \star} \\
(8.6)\end{array}$ \\
\hline NREG Wage & $\begin{array}{l}0.01^{\star \star \star} \\
(0.002)\end{array}$ & $\begin{array}{c}0.003 \\
(0.004)\end{array}$ & $\begin{array}{l}0.002^{\star \star \star} \\
(0.0004)\end{array}$ & $\begin{array}{c}0.08^{\star \star \star} \\
(0.02)\end{array}$ & $\begin{array}{l}0.003^{\star \star \star} \\
(0.0004)\end{array}$ & $\begin{array}{l}0.42^{\star \star \star} \\
(0.10)\end{array}$ & $\begin{array}{c}0.14^{\star \star \star} \\
(0.04)\end{array}$ & $\begin{array}{l}0.32^{\star \star \star} \\
(0.05)\end{array}$ & $\begin{array}{l}0.01^{\star \star \star} \\
(0.001)\end{array}$ & $\begin{array}{l}0.63^{\star \star \star} \\
(0.13)\end{array}$ & $\begin{array}{l}0.001^{\star \star \star} \\
(0.0001)\end{array}$ & $\begin{array}{c}0.0001 \\
(0.0001)\end{array}$ & $\begin{array}{l}0.01^{\star \star \star} \\
(0.001)\end{array}$ & $\begin{array}{l}0.01^{\star \star \star} \\
(0.004)\end{array}$ \\
\hline $\begin{array}{l}\text { Non NREG } \\
\text { Income }\end{array}$ & $\begin{array}{c}0.00003 \\
(0.00002)\end{array}$ & $\begin{array}{c}2 \times 10^{-5} \\
\left(2 \times 10^{-5}\right)\end{array}$ & $\begin{array}{c}3 \times 10^{-6} \\
\left(3 \times 10^{-6}\right)\end{array}$ & $\begin{array}{c}0.0001 \\
(0.0001)\end{array}$ & $\begin{array}{c}4 \times 10^{-6} \\
\left(3 \times 10^{-6}\right)\end{array}$ & $\begin{array}{c}0.001 \\
(0.001)\end{array}$ & $\begin{array}{c}0.0002 \\
(0.0002)\end{array}$ & $\begin{array}{c}0.001^{\star} \\
(0.0004)\end{array}$ & $\begin{array}{l}4 \times 10^{-6} \\
\left(7 \times 10^{-6}\right)\end{array}$ & $\begin{array}{c}0.001 \\
(0.001)\end{array}$ & $\begin{array}{l}8 \times 10^{-7} \\
\left(5 \times 10^{-7}\right)\end{array}$ & $\begin{array}{c}3 \times 10^{-7} \\
\left(3 \times 10^{-7}\right)\end{array}$ & $\begin{array}{l}1 \times 10^{-5 *} \\
\left(7 \times 10^{-6}\right)\end{array}$ & $\begin{array}{l}1 \times 10^{-4 \times x} \\
\left(2 \times 10^{5}\right)\end{array}$ \\
\hline Hindu & $\begin{array}{l}-4.9 \\
(6.9)\end{array}$ & $\begin{array}{c}13.5^{\star \star \star} \\
(4.9)\end{array}$ & $\begin{array}{l}-0.2 \\
(0.9)\end{array}$ & $\begin{array}{l}-104^{*} \\
(57.1)\end{array}$ & $\begin{array}{l}-1.0 \\
(0.9)\end{array}$ & $\begin{array}{l}-321 \\
(299)\end{array}$ & $\begin{array}{l}160^{\star \star \star} \\
(60.2)\end{array}$ & $\begin{array}{c}-57.2 \\
(162.5)\end{array}$ & $\begin{array}{l}-4.1 \\
(3.5)\end{array}$ & $\begin{array}{c}249 \\
(187)\end{array}$ & $\begin{array}{l}-0.23 \\
(0.24)\end{array}$ & $\begin{array}{c}0.02 \\
(0.09)\end{array}$ & $\begin{array}{l}-6^{*} \\
(3.5)\end{array}$ & $\begin{array}{l}-14^{\star *} \\
(7.3)\end{array}$ \\
\hline Muslim & $\begin{array}{c}-12.5^{\star} \\
(7.2)\end{array}$ & $\begin{array}{l}-5.1 \\
(5.4)\end{array}$ & $\begin{array}{l}-2.5^{\star \star \star} \\
(0.96)\end{array}$ & $\begin{array}{l}-80.4 \\
(58.4)\end{array}$ & $\begin{array}{l}-3.8^{\star \star \star \star} \\
(1.0)\end{array}$ & $\begin{array}{l}-429 \\
(306)\end{array}$ & $\begin{array}{l}-124^{\star} \\
(65.5)\end{array}$ & $\begin{array}{l}-335^{\star \star \star} \\
(167)\end{array}$ & $\begin{array}{l}-6.7^{*} \\
(3.6)\end{array}$ & $\begin{array}{l}-467^{\star \star} \\
(201)\end{array}$ & $\begin{array}{l}-0.61^{\star *} \\
(0.25)\end{array}$ & $\begin{array}{c}-0.31^{\star \star \star} \\
(0.09)\end{array}$ & $\begin{array}{l}-6.8^{\star} \\
(3.5)\end{array}$ & $\begin{array}{c}-26^{\star * *} \\
(7.7)\end{array}$ \\
\hline SC & $\begin{array}{l}5.9^{\star \star} \\
(2.5)\end{array}$ & $\begin{array}{l}1.7 \\
(3.7)\end{array}$ & $\begin{array}{l}0.9^{\star \star} \\
(0.4)\end{array}$ & $\begin{array}{l}48.6^{\star \star *} \\
(14.8)\end{array}$ & $\begin{array}{c}0.74 \\
(0.47)\end{array}$ & $\begin{array}{c}236^{\star \star \star} \\
(88)\end{array}$ & $\begin{array}{l}98.7^{\star \star} \\
(43.5)\end{array}$ & $\begin{array}{l}168^{\star \star \star} \\
(62.3)\end{array}$ & $\begin{array}{l}3.1^{\star \star \star} \\
(1.04)\end{array}$ & $\begin{array}{l}455^{\star \star \star} \\
(125)\end{array}$ & $\begin{array}{l}0.17^{\star \star} \\
(0.08)\end{array}$ & $\begin{array}{c}0.06 \\
(0.05)\end{array}$ & $\begin{array}{l}2.7^{\star \star \star} \\
(1.05)\end{array}$ & $\begin{array}{c}11.6^{\star \star \star} \\
(3.8)\end{array}$ \\
\hline Instruments & \multicolumn{14}{|c|}{ Landownership, Distance from the Fair Price Shop, Fair Price Shop waiting time } \\
\hline Observations & 463 & 463 & 463 & 463 & 463 & 463 & 463 & 463 & 463 & 463 & 463 & 463 & 463 & 463 \\
\hline $\begin{array}{l}\text { Endog. test }(p- \\
\quad \text { value) }\end{array}$ & 0.03 & 0.04 & 0.04 & 0.03 & 0.04 & 0.04 & 0.04 & 0.02 & 0.06 & 0.05 & 0.06 & 0.03 & 0.04 & 0.04 \\
\hline $\begin{array}{l}\text { Partial } R^{2} \text { on } \\
\text { instruments }\end{array}$ & 0.003 & 0.003 & 0.003 & 0.003 & 0.003 & 0.003 & 0.003 & 0.003 & 0.003 & 0.003 & 0.003 & 0.003 & 0.003 & 0.003 \\
\hline
\end{tabular}

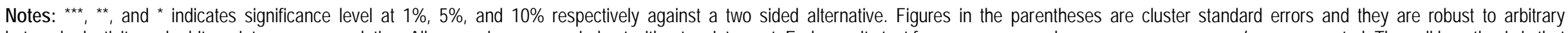
heteroskedasticity and arbitrary intra-group correlation. All regressions are carried out vithout an intercept. Endogeneity test for one or more endogenous regressors $p$-values are reported. The null hypothesis is that the specified endogenous variables can actually be treated as exogenous. Under the null the test statistic follows $\chi^{2}$-distribution with degrees of freedom equal to the number of regressors tested. Note that Sargan overidentification test is not reported as the number of instruments is equal to the number of suspected endogenous variables. Partial $\mathrm{R}^{2}$ on excluded instruments are also reported which measures instrument relevance. 
Table 9: Anti-Poverty Programs and Nutrient Deprivation: Evidence from Rural Rajasthan

\begin{tabular}{|c|c|c|c|c|c|c|c|c|c|c|c|c|c|c|}
\hline & Protein & Fat & Minerals & Carb. & Fiber & Energy & Calcium & $\begin{array}{c}\text { Phospho } \\
\text { rus }\end{array}$ & Iron & Carotene & Thiamine & Riboflavin & Niacin & Vit. C \\
\hline & \multicolumn{14}{|c|}{ IV Estimates } \\
\hline & (1) & (2) & (3) & (4) & (5) & (6) & (7) & (8) & (9) & (10) & (11) & (12) & (13) & (14) \\
\hline PDS Participation & $\begin{array}{l}19.5^{\star} \\
(10.7)\end{array}$ & $\begin{array}{c}2.8 \\
(8.1)\end{array}$ & $\begin{array}{c}2.2 \\
(1.6)\end{array}$ & $\begin{array}{l}143^{\star \star} \\
(62.2)\end{array}$ & $\begin{array}{c}1.4 \\
(1.7)\end{array}$ & $\begin{array}{l}651^{\star} \\
(348)\end{array}$ & $\begin{array}{c}96 \\
(127)\end{array}$ & $\begin{array}{l}486^{\star} \\
(283)\end{array}$ & $\begin{array}{l}9.6^{\star \star} \\
(4.3)\end{array}$ & $\begin{array}{l}96.8 \\
(265)\end{array}$ & $\begin{array}{l}0.76^{\star} \\
(0.38)\end{array}$ & $\begin{array}{c}0.24 \\
(0.19)\end{array}$ & $\begin{array}{l}10^{\star \star} \\
(4.2)\end{array}$ & $\begin{array}{c}6.6 \\
(7.7)\end{array}$ \\
\hline NREG Wage & $\begin{array}{l}0.01^{\star \star \star} \\
(0.002)\end{array}$ & $\begin{array}{c}0.001 \\
(0.002)\end{array}$ & $\begin{array}{c}0.001^{\star \star} \\
(0.0003)\end{array}$ & $\begin{array}{c}0.05^{\star \star \star} \\
(0.01)\end{array}$ & $\begin{array}{l}0.001^{\star \star} \\
(0.0004)\end{array}$ & $\begin{array}{c}0.24^{\star \star \star} \\
(0.09)\end{array}$ & $\begin{array}{c}0.02 \\
(0.03)\end{array}$ & $\begin{array}{l}0.21^{\star \star \star} \\
(0.07)\end{array}$ & $\begin{array}{l}0.003^{\star \star} \\
(0.001)\end{array}$ & $\begin{array}{c}0.01 \\
(0.07)\end{array}$ & $\begin{array}{c}0.0003^{\star \star \star} \\
(0.0001)\end{array}$ & $\begin{array}{c}0.0001^{\star \star} \\
(0.00005)\end{array}$ & $\begin{array}{l}0.003^{\star \star} \\
(0.001)\end{array}$ & $\begin{array}{l}0.0005 \\
(0.002)\end{array}$ \\
\hline $\begin{array}{l}\text { Non NREG } \\
\text { Income }\end{array}$ & $\begin{array}{c}0.001 \\
(0.0004)\end{array}$ & $\begin{array}{l}0.001^{\star *} \\
(0.0003)\end{array}$ & $\begin{array}{c}0.0001 \\
(0.0001)\end{array}$ & $\begin{array}{c}0.003 \\
(0.002)\end{array}$ & $\begin{array}{c}0.0001 \\
(0.0001)\end{array}$ & $\begin{array}{l}0.02^{\star} \\
(0.01)\end{array}$ & $\begin{array}{l}0.01^{\star \star} \\
(0.004)\end{array}$ & $\begin{array}{l}0.016 \\
(0.01)\end{array}$ & $\begin{array}{c}0.0003 \\
(0.0002)\end{array}$ & $\begin{array}{l}0.03^{\star \star} \\
(0.01)\end{array}$ & $\begin{array}{c}0.00002 \\
(0.00001)\end{array}$ & $\begin{array}{l}1 \times 10^{-5} \\
\left(8 \times 10^{6}\right)\end{array}$ & $\begin{array}{c}0.0002 \\
(0.0002)\end{array}$ & $\begin{array}{l}0.0005^{*} \\
(0.0003)\end{array}$ \\
\hline Hindu & $\begin{array}{c}27.5 \\
(48.9)\end{array}$ & $\begin{array}{l}-45.9 \\
(62.3)\end{array}$ & $\begin{array}{c}4.6 \\
(7.1)\end{array}$ & $\begin{array}{l}136 \\
(292)\end{array}$ & $\begin{array}{c}6.8 \\
(6.3)\end{array}$ & $\begin{array}{c}224 \\
(1921)\end{array}$ & $\begin{array}{c}-71 \\
(767)\end{array}$ & $\begin{array}{c}691 \\
(1328)\end{array}$ & $\begin{array}{c}6.7 \\
(20.5)\end{array}$ & $\begin{array}{c}49 \\
(1455)\end{array}$ & $\begin{array}{c}1.03 \\
(1.79)\end{array}$ & $\begin{array}{c}0.5 \\
(0.8)\end{array}$ & $\begin{array}{c}8.1 \\
(20.4)\end{array}$ & $\begin{array}{l}-19.6 \\
(48.3)\end{array}$ \\
\hline SC & $\begin{array}{c}18.8 \\
(19.9)\end{array}$ & $\begin{array}{l}-19.8 \\
(16.4)\end{array}$ & $\begin{array}{c}1.5 \\
(2.9)\end{array}$ & $\begin{array}{c}126 \\
(113)\end{array}$ & $\begin{array}{c}1.1 \\
(3.01)\end{array}$ & $\begin{array}{c}398 \\
(634)\end{array}$ & $\begin{array}{l}-251 \\
(254)\end{array}$ & $\begin{array}{l}548 \\
(521)\end{array}$ & $\begin{array}{c}4.2 \\
(8.1)\end{array}$ & $\begin{array}{l}-878^{\star} \\
(505)\end{array}$ & $\begin{array}{c}0.82 \\
(0.72)\end{array}$ & $\begin{array}{c}0.2 \\
(0.3)\end{array}$ & $\begin{array}{c}6.3 \\
(8.6)\end{array}$ & $\begin{array}{l}-22 \\
(16)\end{array}$ \\
\hline ST & $\begin{array}{c}7.3 \\
(19.9)\end{array}$ & $\begin{array}{l}-20.4 \\
(16.3)\end{array}$ & $\begin{array}{c}0.4 \\
(2.9)\end{array}$ & $\begin{array}{c}56 \\
(113)\end{array}$ & $\begin{array}{c}2.9 \\
(3.05)\end{array}$ & $\begin{array}{c}43 \\
(632)\end{array}$ & $\begin{array}{l}-493^{\star} \\
(256)\end{array}$ & $\begin{array}{l}159 \\
(520)\end{array}$ & $\begin{array}{l}-1.5 \\
(8.1)\end{array}$ & $\begin{array}{l}-822 \\
(510)\end{array}$ & $\begin{array}{c}0.29 \\
(0.72)\end{array}$ & $\begin{array}{c}0.04 \\
(0.33)\end{array}$ & $\begin{array}{l}-1.4 \\
(8.5)\end{array}$ & $\begin{array}{l}-26 \\
(16)\end{array}$ \\
\hline Instruments & \multicolumn{14}{|c|}{ Landownership, Distance from the Fair Price Shop, Fair Price Shop waiting time } \\
\hline Observations & 460 & 460 & 460 & 460 & 460 & 460 & 460 & 460 & 460 & 460 & 460 & 460 & 460 & 460 \\
\hline $\begin{array}{c}\text { Endog. test }(p- \\
\text { value })\end{array}$ & 0.07 & 0.07 & 0.06 & 0.07 & 0.07 & 0.07 & 0.09 & 0.07 & 0.07 & 0.07 & 0.06 & 0.06 & 0.07 & 0.07 \\
\hline $\begin{array}{l}\text { Partial } R^{2} \text { on } \\
\text { instruments }\end{array}$ & 0.004 & 0.004 & 0.004 & 0.004 & 0.004 & 0.004 & 0.004 & 0.004 & 0.004 & 0.004 & 0.004 & 0.004 & 0.004 & 0.004 \\
\hline
\end{tabular}

Notes: ***, **, and * indicates significance level at 1\%,5\%, and 10\% respectively against a two sided alternative. Figures in the parentheses are cluster standard errors and they are robust to arbitrary heteroskedasticity and arbitrary intra-group correlation. All regressions are carried out without an intercept. Endogeneity test for one or more endogenous regressors $p$-values are reported. The null hypothesis is that the specified endogenous variables can actually be treated as exogenous. Under the null the test statistic follows $\chi^{2}$-distribution with degrees of freedom equal to the number of regressors tested. Note that Sargan overidentification test is not reported as the number of instruments is equal to the number of suspected endogenous variables. Aso note that the Muslim dummy is dropped in this case as there are no Muslims in our Rajasthan sample. 
Table 10: Anti-Poverty Programs and Nutrient Deprivation: First Stage Regressions

\begin{tabular}{|c|c|c|c|c|c|c|c|c|c|}
\hline & \multicolumn{3}{|c|}{ Andhra Pradesh } & \multicolumn{3}{|c|}{ Maharashtra } & \multicolumn{3}{|c|}{ Rajasthan } \\
\hline & \multicolumn{9}{|c|}{ OLS Estimates } \\
\hline & $\begin{array}{c}\text { PDS } \\
\text { Participation } \\
\text { (1) } \\
\end{array}$ & $\begin{array}{c}\text { NREG Wage } \\
\text { (2) }\end{array}$ & $\begin{array}{c}\text { Non NREG } \\
\text { Income } \\
(3)\end{array}$ & $\begin{array}{c}\text { PDS } \\
\text { Participation } \\
\text { (4) }\end{array}$ & $\begin{array}{c}\text { NREG Wage } \\
\text { (5) }\end{array}$ & $\begin{array}{c}\text { Non NREG } \\
\text { Income } \\
(6)\end{array}$ & $\begin{array}{c}\text { PDS } \\
\text { Participation } \\
\text { (7) }\end{array}$ & $\begin{array}{c}\text { NREG Wage } \\
\text { (8) }\end{array}$ & $\begin{array}{c}\text { Non NREG } \\
\text { Income } \\
(9) \\
\end{array}$ \\
\hline $\begin{array}{l}\text { Landownership } \\
\text { Distance from the } \\
\text { Fair Price Shop }\end{array}$ & $\begin{array}{c}-0.02^{\star \star \star} \\
(0.003) \\
0.006 \\
(0.009)\end{array}$ & $\begin{array}{c}-32.8 \\
(66.8) \\
-307.7^{\star} \\
(158)\end{array}$ & $\begin{array}{c}5772^{\star \star \star} \\
(426) \\
-5323^{\star \star \star} \\
(1010)\end{array}$ & $\begin{array}{l}-0.04^{\star \star \star} \\
(0.005) \\
-0.005 \\
(0.03)\end{array}$ & $\begin{array}{l}-62.9^{\star \star \star} \\
(13) \\
-217^{\star \star} \\
(86.9)\end{array}$ & $\begin{array}{c}8559^{\star \star \star} \\
(373) \\
-6883^{\star \star \star} \\
(2483)\end{array}$ & $\begin{array}{c}-0.01^{\star \star \star} \\
(0.003) \\
-0.01 \\
(0.01)\end{array}$ & $\begin{array}{c}-70.5^{\star \star \star} \\
(15.7) \\
-51.6 \\
(42.7)\end{array}$ & $\begin{array}{l}2353^{\star \star \star} \\
(325) \\
-2112^{\star \star} \\
(884)\end{array}$ \\
\hline $\begin{array}{l}\text { Fair Price Shop } \\
\text { waiting time }\end{array}$ & $\begin{array}{c}0.0002 \\
(0.0002)\end{array}$ & $\begin{array}{l}0.94 \\
(3.6)\end{array}$ & $\begin{array}{l}-33.1 \\
(23.4)\end{array}$ & $\begin{array}{l}0.004^{\star \star} \\
(0.001)\end{array}$ & $\begin{array}{l}-0.47 \\
(5.1)\end{array}$ & $\begin{array}{c}3.2 \\
(146)\end{array}$ & $\begin{array}{l}0.002^{\star \star \star} \\
(0.0004)\end{array}$ & $\begin{array}{l}-0.02 \\
(1.6)\end{array}$ & $\begin{array}{l}-49.5 \\
(33.2)\end{array}$ \\
\hline Hindu & $\begin{array}{l}-0.03 \\
(0.09)\end{array}$ & $\begin{array}{l}-1035 \\
(1579)\end{array}$ & $\begin{array}{l}-10405 \\
(10093)\end{array}$ & $\begin{array}{l}0.05 \\
(0.15)\end{array}$ & $\begin{array}{l}19.9 \\
(432)\end{array}$ & $\begin{array}{c}2369 \\
(12347)\end{array}$ & $\begin{array}{l}-0.006 \\
(0.24)\end{array}$ & $\begin{array}{c}314 \\
(960)\end{array}$ & $\begin{array}{l}20190 \\
(19923)\end{array}$ \\
\hline Muslim & $\begin{array}{l}-0.02 \\
(0.1)\end{array}$ & $\begin{array}{l}-1401 \\
(1737)\end{array}$ & $\begin{array}{c}9365 \\
(11106)\end{array}$ & $\begin{array}{c}0.49 \\
(0.48)\end{array}$ & $\begin{array}{l}-1675 \\
(1302)\end{array}$ & $\begin{array}{c}42252 \\
(37238)\end{array}$ & & & \\
\hline SC & $\begin{array}{l}0.006 \\
(0.02)\end{array}$ & $\begin{array}{c}339 \\
(372)\end{array}$ & $\begin{array}{l}-1836 \\
(2379)\end{array}$ & $\begin{array}{l}0.22^{\star \star \star} \\
(0.08)\end{array}$ & $\begin{array}{l}-477^{\star *} \\
(226)\end{array}$ & $\begin{array}{c}-10783^{\star} \\
(6459)\end{array}$ & $\begin{array}{l}0.08 \\
(0.1)\end{array}$ & $\begin{array}{l}168 \\
(401)\end{array}$ & $\begin{array}{c}-43535^{\star \star \star} \\
(8324)\end{array}$ \\
\hline ST & $\begin{array}{l}0.002 \\
(0.03)\end{array}$ & $\begin{array}{l}1192^{\star \star \star} \\
(444.7)\end{array}$ & $\begin{array}{c}1426 \\
(2842)\end{array}$ & $\begin{array}{l}0.28^{\star \star \star} \\
(0.07)\end{array}$ & $\begin{array}{l}-274 \\
(198)\end{array}$ & $\begin{array}{c}-11937^{\star \star} \\
(5680)\end{array}$ & $\begin{array}{c}0.3^{\star \star \star} \\
(0.1)\end{array}$ & $\begin{array}{c}478 \\
(398)\end{array}$ & $\begin{array}{c}-38991^{\star \star \star} \\
(8267)\end{array}$ \\
\hline $\mathrm{OBC}$ & $\begin{array}{c}0.01 \\
(0.02)\end{array}$ & $\begin{array}{l}-76.7 \\
(346)\end{array}$ & $\begin{array}{c}198 \\
(2213)\end{array}$ & $\begin{array}{c}0.04 \\
(0.05)\end{array}$ & $\begin{array}{c}-300^{\star *} \\
(151)\end{array}$ & $\begin{array}{c}-11951^{\star \star \star} \\
(4325)\end{array}$ & $\begin{array}{c}0.09 \\
(0.09)\end{array}$ & $\begin{array}{r}95.1 \\
(391)\end{array}$ & $\begin{array}{c}-34034^{\star \star \star} \\
(8126)\end{array}$ \\
\hline $\begin{array}{c}\text { Observations } \\
\text { Adjusted } \mathrm{R}^{2} \\
\text { F-Stat }\end{array}$ & $\begin{array}{l}464 \\
0.05 \\
2.73\end{array}$ & $\begin{array}{l}464 \\
0.04 \\
2.27\end{array}$ & $\begin{array}{l}464 \\
0.33 \\
28.3\end{array}$ & $\begin{array}{l}463 \\
0.20 \\
14.2\end{array}$ & $\begin{array}{l}463 \\
0.10 \\
4.53\end{array}$ & $\begin{array}{l}463 \\
0.57 \\
74.3\end{array}$ & $\begin{array}{l}460 \\
0.11 \\
7.92\end{array}$ & $\begin{array}{c}460 \\
0.06 \\
4.1\end{array}$ & $\begin{array}{c}460 \\
0.17 \\
13.52\end{array}$ \\
\hline
\end{tabular}

Notes: ***, **, and * indicates significance level at 1\%,5\%, and 10\% respectively against a two sided alternative. Figures in the parentheses are cluster standard errors and they are robust to arbitrary heteroskedasticity and arbitrary intra-group correlation. All regressions are carried out without an intercept. F-Stat is compared with the Stock and Yogo $10 \%$ critical value which is 13.4 . The critical value indicates that the IV bias is $10 \%$ If $F$-Stat is greater than this value then the instruments are strong and the bias is less than $10 \%$ Atternatively, the instruments are weak. 
Table 11: Anti-Poverty Programs and Nutrient Deprivation: Results Summary

\begin{tabular}{|c|c|c|c|c|c|c|}
\hline \multirow{2}{*}{ Nutrients } & \multicolumn{2}{|c|}{ Andhra Pradesh } & \multicolumn{2}{|c|}{ Maharashtra } & \multicolumn{2}{|c|}{ Rajasthan } \\
\hline & $\begin{array}{l}\text { OLS \& IV Individual } \\
\text { Equation Estimates }\end{array}$ & Systems SUR Estimates & $\begin{array}{l}\text { OLS \& IV Individual } \\
\text { Equation Estimates }\end{array}$ & Systems SUR Estimates & $\begin{array}{l}\text { OLS \& IV Individual } \\
\text { Equation Estimates }\end{array}$ & Systems SUR Estimates \\
\hline Protein & $\begin{array}{l}\text { NREG and PDS significant } \\
\text { and positive }\end{array}$ & $\begin{array}{l}\text { NREG and PDS significant } \\
\text { and positive }\end{array}$ & $\begin{array}{c}\text { NREG and PDS significant } \\
\text { and positive }\end{array}$ & $\begin{array}{c}\text { NREG and PDS significant } \\
\text { and positive }\end{array}$ & $\begin{array}{c}\text { NREG and PDS significant } \\
\text { and positive }\end{array}$ & $\begin{array}{c}\text { NREG and PDS significant } \\
\text { and positive }\end{array}$ \\
\hline Fat & $\begin{array}{c}\text { NREG not significant and } \\
\text { PDS significant }\end{array}$ & $\begin{array}{c}\text { NREG not significant and } \\
\text { PDS significant }\end{array}$ & Neither significant & Neither significant & Neither significant & Neither significant \\
\hline Minerals & $\begin{array}{l}\text { NREG and PDS significant } \\
\text { and positive }\end{array}$ & $\begin{array}{l}\text { NREG and PDS significant } \\
\text { and positive }\end{array}$ & $\begin{array}{l}\text { NREG and PDS significant } \\
\text { and positive }\end{array}$ & $\begin{array}{l}\text { NREG and PDS significant } \\
\text { and positive }\end{array}$ & $\begin{array}{c}\text { NREG significant PDS not } \\
\text { significant }\end{array}$ & $\begin{array}{c}\text { NREG significant PDS not } \\
\text { significant }\end{array}$ \\
\hline Carbohydrates & $\begin{array}{l}\text { NREG and PDS significant } \\
\text { and positive }\end{array}$ & $\begin{array}{l}\text { NREG and PDS significant } \\
\text { and positive }\end{array}$ & $\begin{array}{c}\text { NREG and PDS significant } \\
\text { and positive }\end{array}$ & $\begin{array}{c}\text { NREG and PDS significant } \\
\text { and positive }\end{array}$ & $\begin{array}{c}\text { NREG and PDS significant } \\
\text { and positive }\end{array}$ & $\begin{array}{c}\text { NREG and PDS significant } \\
\text { and positive }\end{array}$ \\
\hline Fibre & Neither significant & Neither significant & $\begin{array}{l}\text { NREG and PDS significant } \\
\text { and positive }\end{array}$ & $\begin{array}{l}\text { NREG and PDS significant } \\
\text { and positive }\end{array}$ & $\begin{array}{c}\text { NREG significant PDS not } \\
\text { significant }\end{array}$ & $\begin{array}{c}\text { NREG significant PDS not } \\
\text { significant }\end{array}$ \\
\hline Energy & $\begin{array}{l}\text { NREG and PDS significant } \\
\text { and positive }\end{array}$ & $\begin{array}{l}\text { NREG and PDS significant } \\
\text { and positive }\end{array}$ & $\begin{array}{c}\text { NREG and PDS significant } \\
\text { and positive }\end{array}$ & $\begin{array}{c}\text { NREG and PDS significant } \\
\text { and positive }\end{array}$ & $\begin{array}{c}\text { NREG and PDS significant } \\
\text { and positive }\end{array}$ & $\begin{array}{l}\text { NREG and PDS significant } \\
\text { and positive }\end{array}$ \\
\hline Calcium & $\begin{array}{c}\text { NREG not significant and } \\
\text { PDS significant }\end{array}$ & $\begin{array}{c}\text { NREG not significant and } \\
\text { PDS significant }\end{array}$ & $\begin{array}{c}\text { NREG and PDS significant } \\
\text { and positive }\end{array}$ & $\begin{array}{c}\text { NREG and PDS significant } \\
\text { and positive }\end{array}$ & Neither significant & Neither significant \\
\hline Phosphorus & $\begin{array}{l}\text { NREG and PDS significant } \\
\text { and positive }\end{array}$ & $\begin{array}{l}\text { NREG and PDS significant } \\
\text { and positive }\end{array}$ & $\begin{array}{c}\text { NREG and PDS significant } \\
\text { and positive }\end{array}$ & $\begin{array}{c}\text { NREG and PDS significant } \\
\text { and positive }\end{array}$ & $\begin{array}{c}\text { NREG and PDS significant } \\
\text { and positive }\end{array}$ & $\begin{array}{c}\text { NREG and PDS significant } \\
\text { and positive }\end{array}$ \\
\hline Iron & $\begin{array}{l}\text { NREG and PDS significant } \\
\text { and positive }\end{array}$ & $\begin{array}{l}\text { NREG and PDS significant } \\
\text { and positive }\end{array}$ & $\begin{array}{c}\text { NREG and PDS significant } \\
\text { and positive }\end{array}$ & $\begin{array}{c}\text { NREG and PDS significant } \\
\text { and positive }\end{array}$ & $\begin{array}{l}\text { NREG and PDS significant } \\
\text { and positive }\end{array}$ & $\begin{array}{c}\text { NREG and PDS significant } \\
\text { and positive }\end{array}$ \\
\hline Carotene & $\begin{array}{c}\text { NREG not significant and } \\
\text { PDS significant }\end{array}$ & $\begin{array}{c}\text { NREG not significant and } \\
\text { PDS significant }\end{array}$ & $\begin{array}{c}\text { NREG and PDS significant } \\
\text { and positive }\end{array}$ & $\begin{array}{l}\text { NREG and PDS significant } \\
\text { and positive }\end{array}$ & Neither significant & Neither significant \\
\hline Thiamine & $\begin{array}{l}\text { NREG and PDS significant } \\
\text { and positive }\end{array}$ & $\begin{array}{l}\text { NREG and PDS significant } \\
\text { and positive }\end{array}$ & $\begin{array}{l}\text { NREG and PDS significant } \\
\text { and positive }\end{array}$ & $\begin{array}{l}\text { NREG and PDS significant } \\
\text { and positive }\end{array}$ & $\begin{array}{l}\text { NREG and PDS significant } \\
\text { and positive }\end{array}$ & $\begin{array}{l}\text { NREG and PDS significant } \\
\text { and positive }\end{array}$ \\
\hline Riboflavin & $\begin{array}{c}\text { NREG not significant and } \\
\text { PDS significant }\end{array}$ & $\begin{array}{c}\text { NREG not significant and } \\
\text { PDS significant }\end{array}$ & $\begin{array}{c}\text { NREG not significant and } \\
\text { PDS significant }\end{array}$ & $\begin{array}{c}\text { NREG not significant and } \\
\text { PDS significant }\end{array}$ & $\begin{array}{c}\text { NREG significant PDS not } \\
\text { significant }\end{array}$ & $\begin{array}{c}\text { NREG significant PDS not } \\
\text { significant }\end{array}$ \\
\hline Niacin & $\begin{array}{l}\text { NREG and PDS significant } \\
\text { and positive }\end{array}$ & $\begin{array}{l}\text { NREG and PDS significant } \\
\text { and positive }\end{array}$ & $\begin{array}{l}\text { NREG and PDS significant } \\
\text { and positive }\end{array}$ & $\begin{array}{l}\text { NREG and PDS significant } \\
\text { and positive }\end{array}$ & $\begin{array}{l}\text { NREG and PDS significant } \\
\text { and positive }\end{array}$ & $\begin{array}{l}\text { NREG and PDS significant } \\
\text { and positive }\end{array}$ \\
\hline Vitamin C & $\begin{array}{c}\text { NREG not significant and } \\
\text { PDS significant }\end{array}$ & $\begin{array}{c}\text { NREG not significant and } \\
\text { PDS significant }\end{array}$ & $\begin{array}{c}\text { NREG and PDS significant } \\
\text { and positive }\end{array}$ & $\begin{array}{c}\text { NREG and PDS significant } \\
\text { and positive }\end{array}$ & Neither significant & Neither significant \\
\hline
\end{tabular}

Notes: OLS: Ordinary Least Squares; IV: Instrumental Variable; SUR: Seemingly Unrelated Regressions. 
Table 12: Impact Coefficients of PDS Participation and NREG Wage on Nutrients

\begin{tabular}{|c|c|c|c|c|c|c|}
\hline & \multicolumn{2}{|l|}{ Andhra Pradesh } & \multicolumn{2}{|l|}{ Maharashtra } & \multicolumn{2}{|l|}{ Rajasthan } \\
\hline & $\begin{array}{l}\text { One SD increase in PDS } \\
\text { participation }\end{array}$ & $\begin{array}{l}\text { One SD increase in NREG } \\
\text { wage }\end{array}$ & $\begin{array}{l}\text { One SD increase in PDS } \\
\text { participation }\end{array}$ & $\begin{array}{l}\text { One SD increase in NREG } \\
\text { wage }\end{array}$ & $\begin{array}{l}\text { One SD increase in PDS } \\
\text { participation }\end{array}$ & $\begin{array}{l}\text { One SD increase in NREG } \\
\text { wage }\end{array}$ \\
\hline Protein & $3.542^{\star \star \star}$ & $2.2159^{\star \star}$ & $6.5868^{\star \star \star}$ & $11.717^{\star \star \star}$ & $18.72^{\star}$ & $20.579^{\star \star \star}$ \\
\hline Fats & $2.645^{\star \star \star}$ & 0.0398862 & 0.9481 & 3.5151 & 2.688 & 2.0579 \\
\hline Minerals & $0.437^{\star \star \star}$ & $0.022159^{*}$ & $1.1976^{\star \star \star}$ & $2.3434^{\star \star \star}$ & 2.112 & $2.0579^{\star \star *}$ \\
\hline Carbohydrates & $27.071^{\star \star \star}$ & $8.8636^{\star *}$ & $35.5787^{\star \star}$ & $93.736^{\star \star \star}$ & $137.28^{\star \star}$ & $102.895^{\star \star \star}$ \\
\hline Fiber & 0.2277 & 0.22159 & $1.4471^{\star \star \star}$ & $3.5151^{\star \star \star}$ & 1.344 & $2.0579^{\star \star}$ \\
\hline Energy & $146.74^{\star \star \star}$ & $44.318^{\star \star}$ & $173.153^{\star \star}$ & $492.114^{\star \star \star}$ & $624.96^{\star}$ & $493.896^{\star \star \star ~}$ \\
\hline Calcium & $20.7^{\star}$ & -2.2159 & $93.812^{\star \star}$ & $164.038^{\star \star \star}$ & 92.16 & 41.158 \\
\hline Phosphorus & $68.77^{\star \star \star}$ & $22.159^{\star}$ & $144.71^{\star \star \star}$ & $374.944^{\star \star \star}$ & $466.56^{\star}$ & $432.159^{\star \star \star}$ \\
\hline Iron & $1.61^{\star \star \star}$ & $0.44318^{\star}$ & $4.2914^{\star \star \star}$ & $11.717^{\star \star \star}$ & $9.216^{\star *}$ & $6.1737^{\star \star}$ \\
\hline Carotene & $72.22^{\star \star \star}$ & -4.4318 & $76.846^{\star \star *}$ & $738.171^{\star \star \star}$ & 92.928 & 20.579 \\
\hline Thiamine & $0.0828^{\star \star}$ & $0.044318^{\star \star}$ & $0.22455^{\star \star \star}$ & $1.1717^{\star \star \star}$ & $0.7296^{\star}$ & $0.61737^{\star \star \star}$ \\
\hline Riboflavin & $0.0368^{\star \star \star}$ & 0.0066477 & $0.08483^{\star}$ & 0.11717 & 0.2304 & $0.20579^{\star \star}$ \\
\hline Niacin & $1.357^{\star \star \star}$ & $0.66477^{\star}$ & $1.7964^{\star}$ & $11.717^{\star \star \star}$ & $9.6^{\star \star}$ & $6.1737^{\star \star}$ \\
\hline Vitamin C & $2.024^{\star \star \star}$ & 0.66477 & $20.459^{\star x \star}$ & $11.717^{\star \star \star ~}$ & 6.336 & 1.02895 \\
\hline
\end{tabular}

N.B. (i) The impact coefficient is computed by multiplying the estimated coefficient by the sample standard deviation, e.g., we multiply the coefficient for proten by the standard deviation of protein consumption in the sample.

(ii) ${ }^{*}, * \star, * \star$ indicates significance at 10,5 and $1 \%$ respectively. 
Table 13: Effect of Rs 100 Increase in Per Capita Income on Nutritional Poverty

\begin{tabular}{|c|c|c|c|c|c|c|c|c|c|}
\hline & \multicolumn{3}{|c|}{ Rajasthan } & \multicolumn{3}{|c|}{ Andhra Pradesh } & \multicolumn{3}{|c|}{ Maharashtra } \\
\hline & $\Delta c / \Delta y$ & $\Delta \% p / \Delta c$ & $\Delta \% p / \Delta y$ & $\Delta c / \Delta y$ & $\Delta \% p / \Delta c$ & $\Delta \% p / \Delta y$ & $\Delta c / \Delta y$ & $\Delta \% p / \Delta c$ & $\Delta \% p / \Delta y$ \\
\hline Calories & 0.032 & 4 & 0.13 & 0.042 & 7 & 0.29 & 0.012 & 20 & 0.24 \\
\hline Protein & 0.001 & 22 & 0.022 & 0.001 & 18 & 0.02 & 0.003 & 18 & 0.05 \\
\hline Calcium & 0.048 & 24 & 1.15 & 0.017 & 11 & 0.19 & 0.01 & 36 & 0.36 \\
\hline Iron & 0.0002 & 17 & 0.003 & 0.001 & 13 & 0.013 & 0.0001 & 29 & 0.003 \\
\hline Carotene & 0.11 & 1 & 0.11 & 0.048 & 3 & 0.144 & 0.01 & 4 & 0.04 \\
\hline Thiamine & 0.00002 & 31 & 0.0006 & 0.00003 & 18 & 0.001 & 0.00002 & 46 & 0.001 \\
\hline Riboflavin & 0.00003 & 2 & 0.0001 & 0.00002 & 1 & 0.00002 & 0.00001 & 1 & 0.00001 \\
\hline Vitamin C & 0.002 & 5 & 0.01 & 0.002 & 16 & 0.03 & 0.0004 & 19 & 0.01 \\
\hline Niacin & 0.0001 & 22 & 0.002 & 0.0004 & 14 & 0.006 & 0.001 & 23 & 0.023 \\
\hline
\end{tabular}

Note: Hundred rupees transfer to individuals in the neighborhood of the poverty line would lead to an increase in consumption given by $\Delta c / \Delta y$. In other words, this is the slope of the consumption-income schedule (reported in Figure 1) in the neighborhood of the poverty line. The $\Delta \% p / \Delta c$ calculated in the neighborhood of the nutritional cutoffs (reported in Appendix I) is the percentage of population pushed above the cut off due to an increase in consumption. Therefore, $\Delta \% p / \Delta y=[\Delta \% p / \Delta c] \times[\Delta c / \Delta y]$ is a short hand measure of the effect of an increase in income on nutritional poverty. 


\section{Figure 1: Consumption-Income Scatter Plots}

\section{Andhra Pradesh}
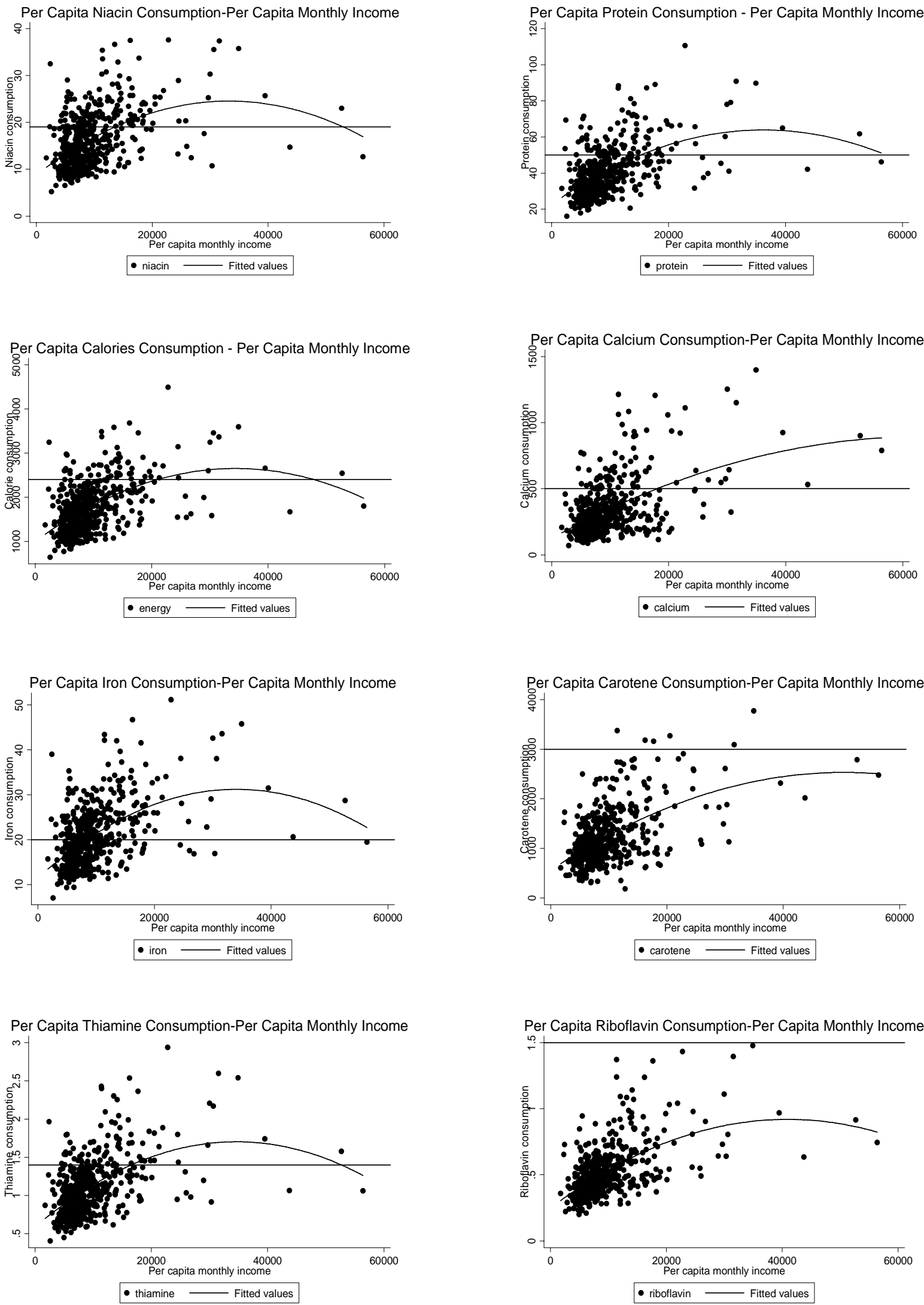


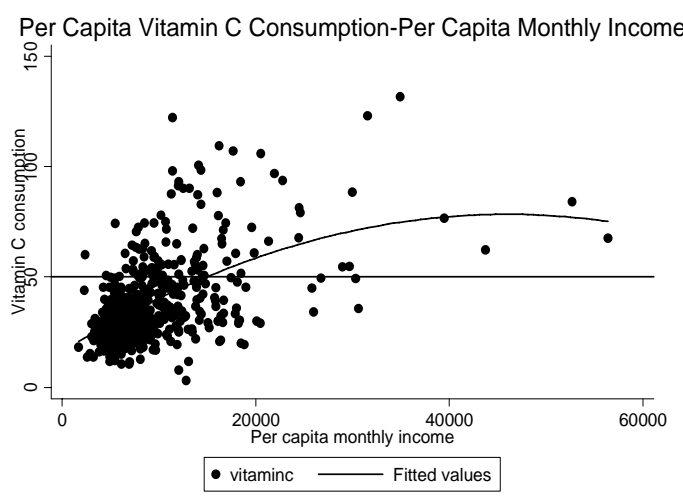

\section{Maharashtra}
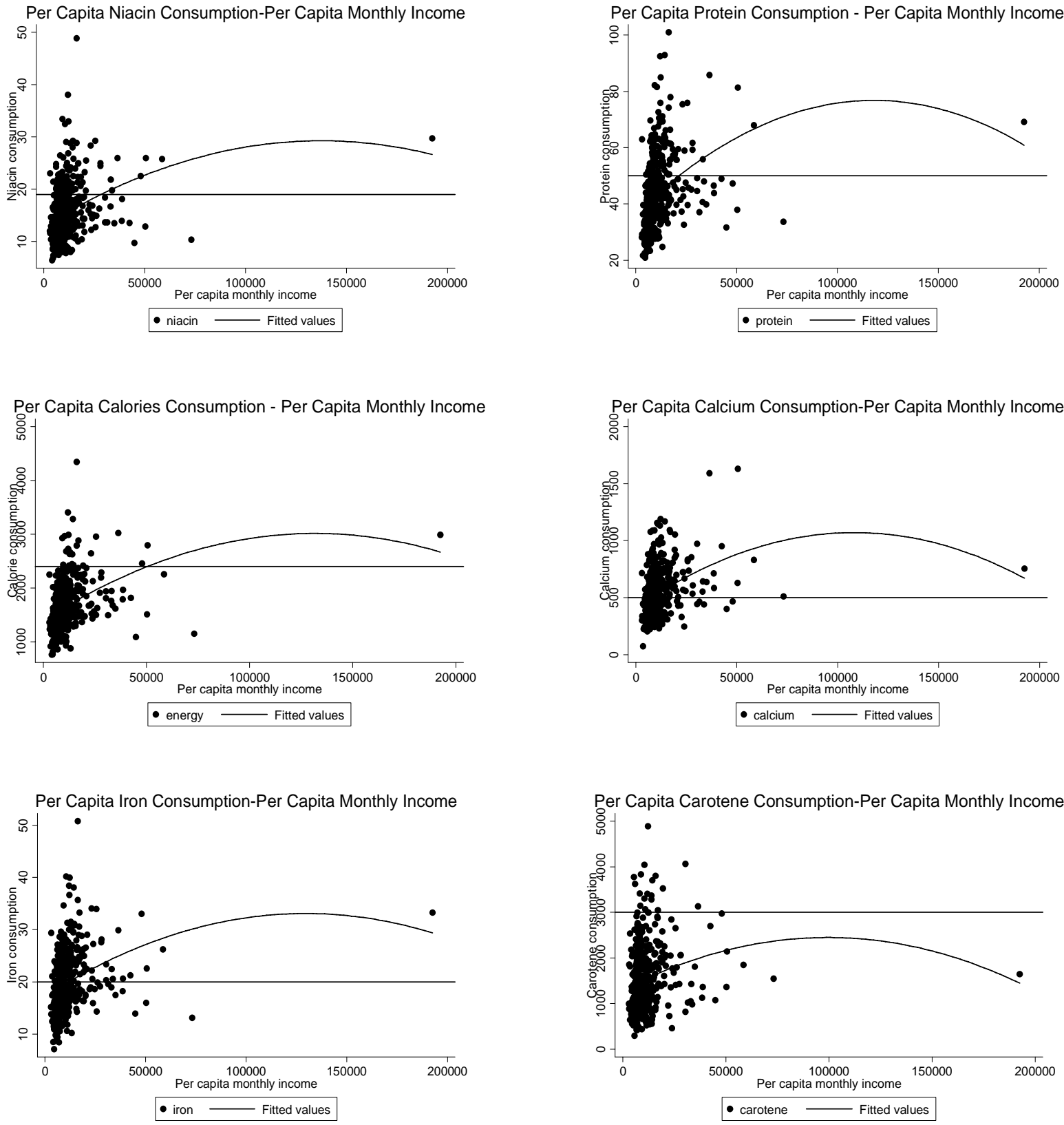

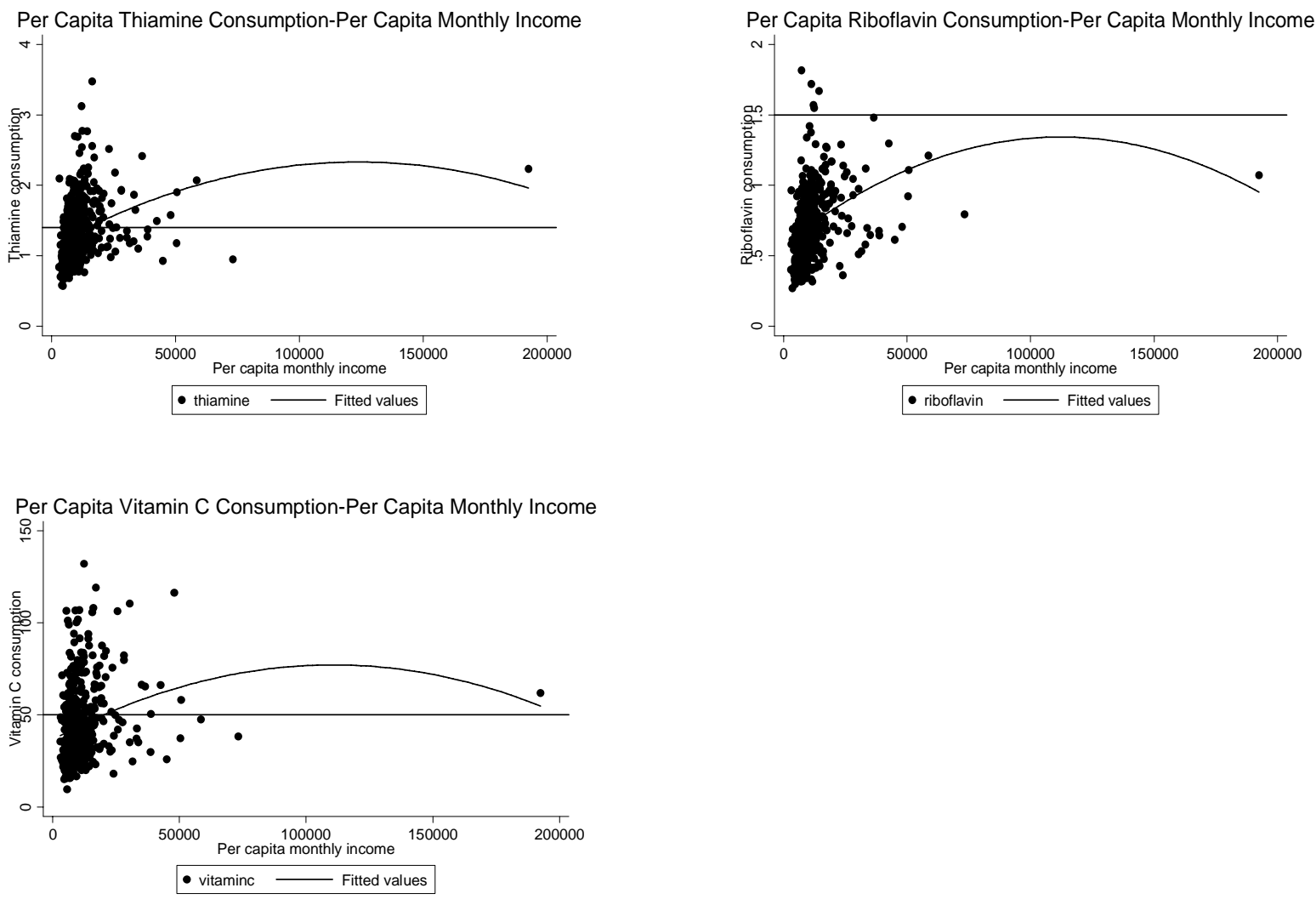

\section{Rajasthan}
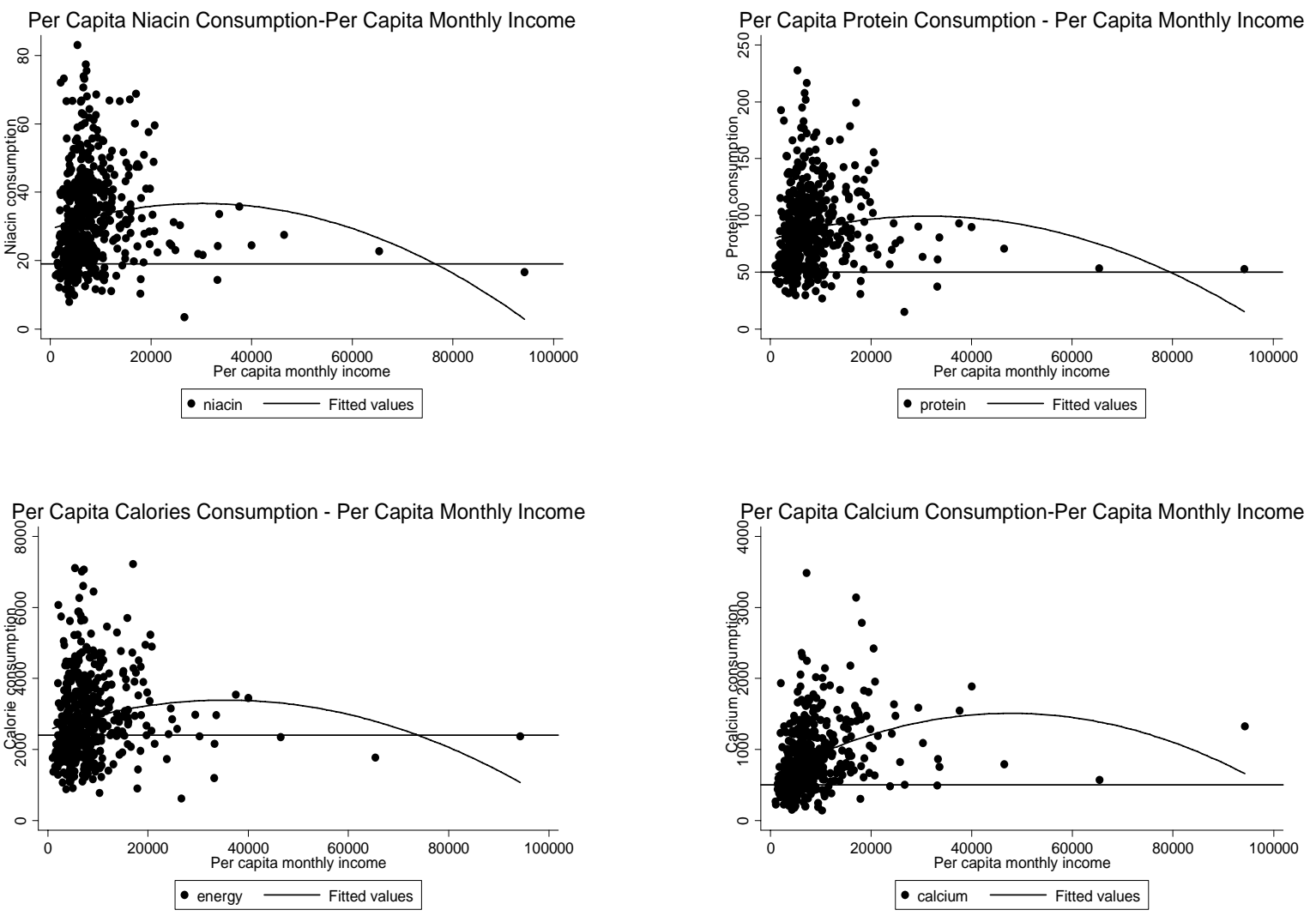

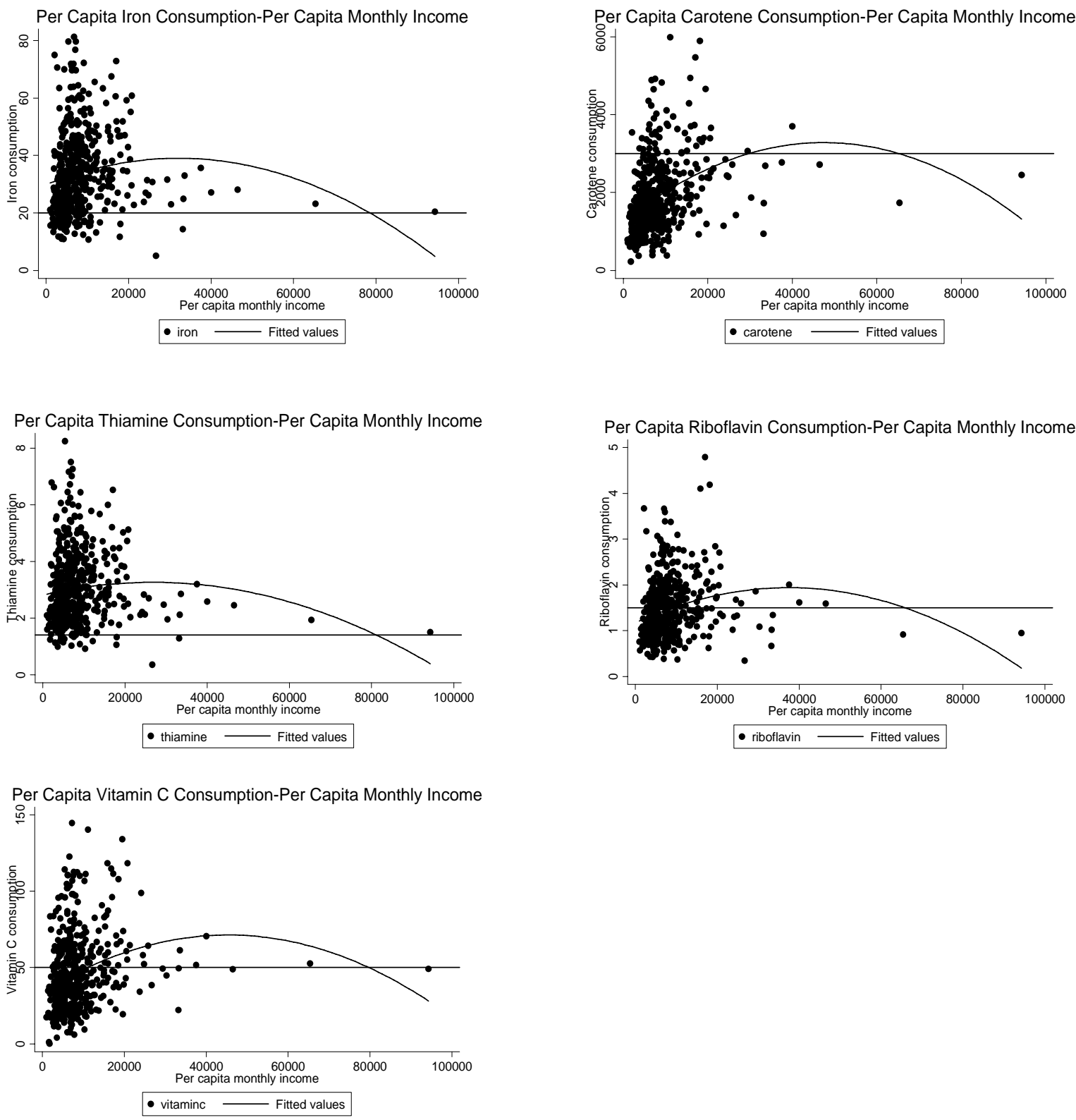

Note: Note that the horizontal lines signify nutritional cut offs of different nutrients reported in Appendix I. 
Figure 2: Distribution of Consumption: Cumulative Distribution Function Plots

\section{Andhra Pradesh}
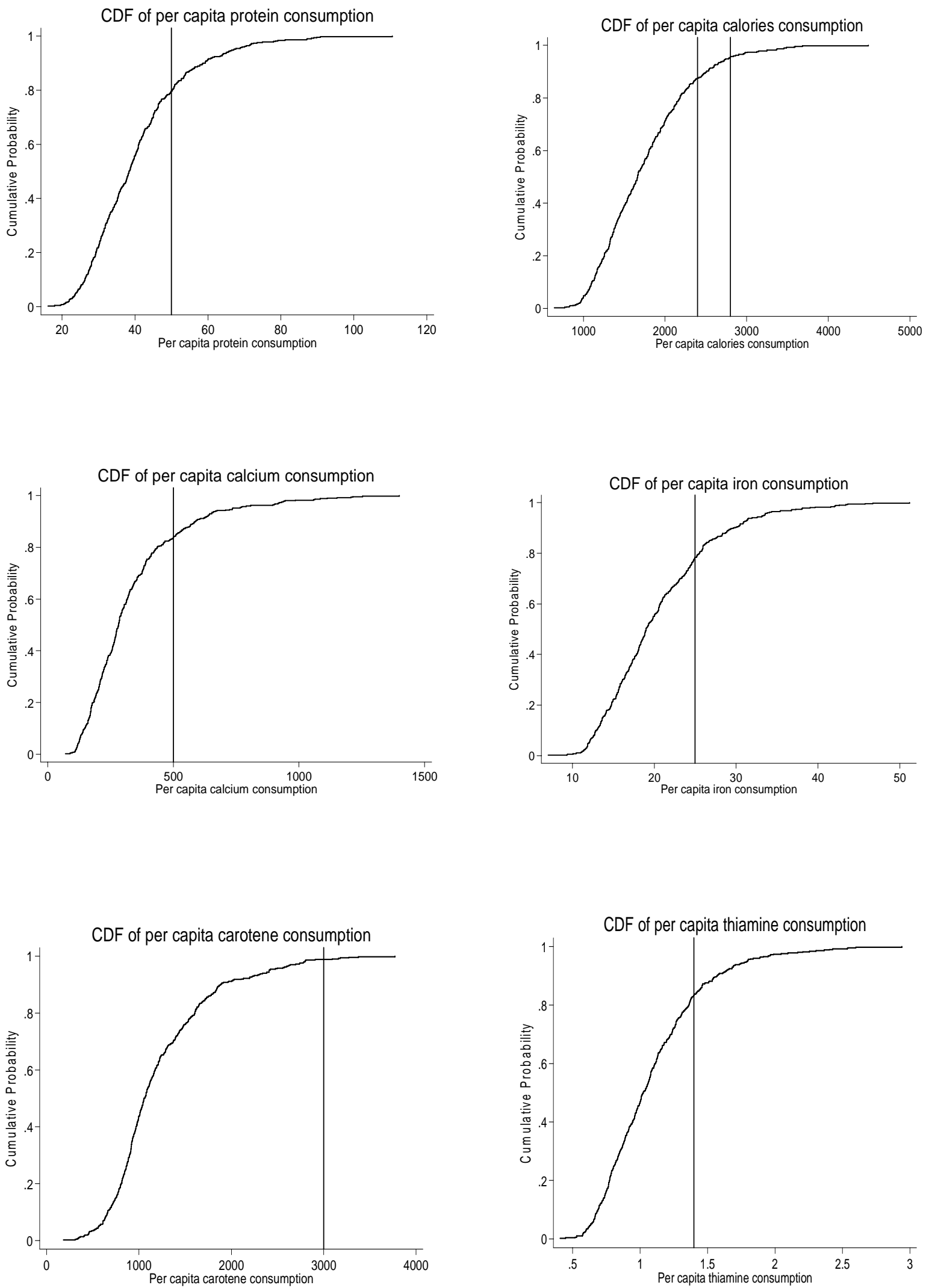

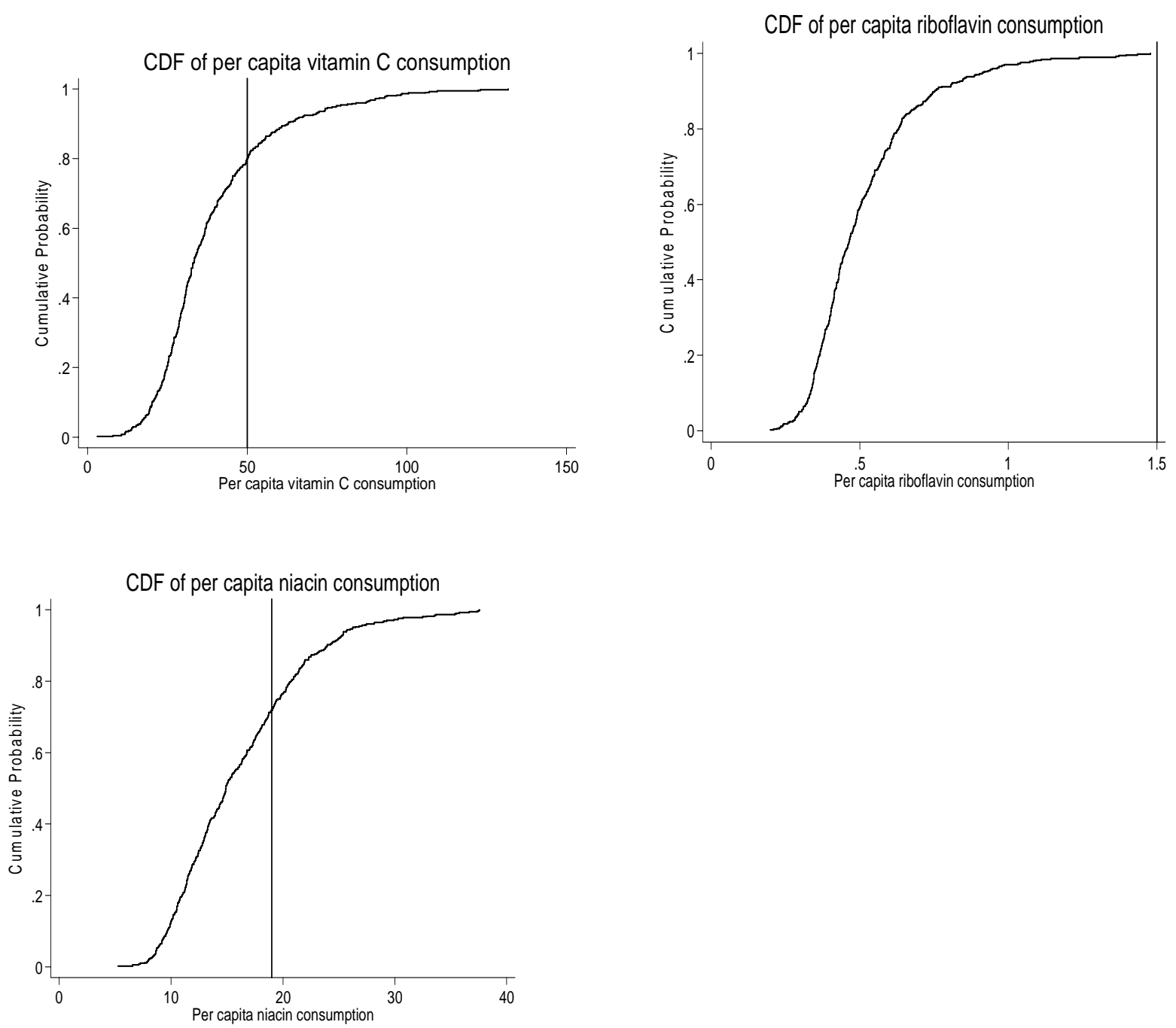

\section{Maharashtra}
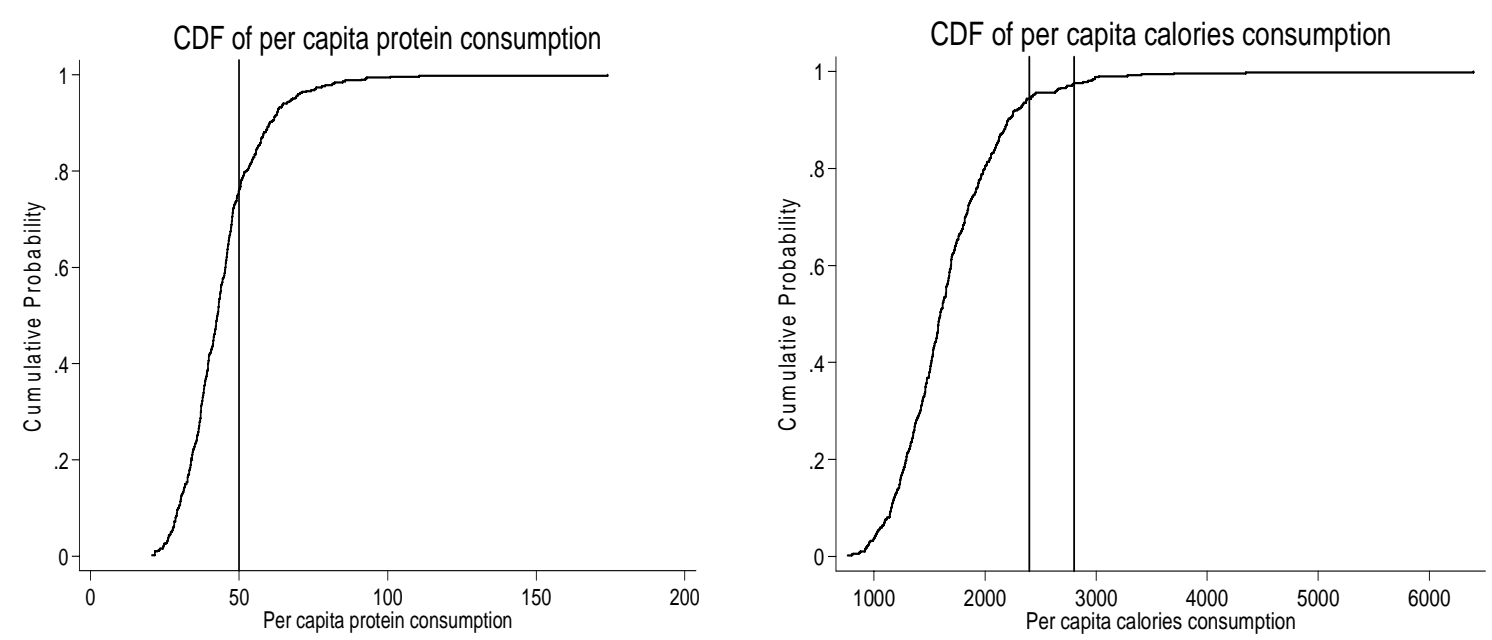

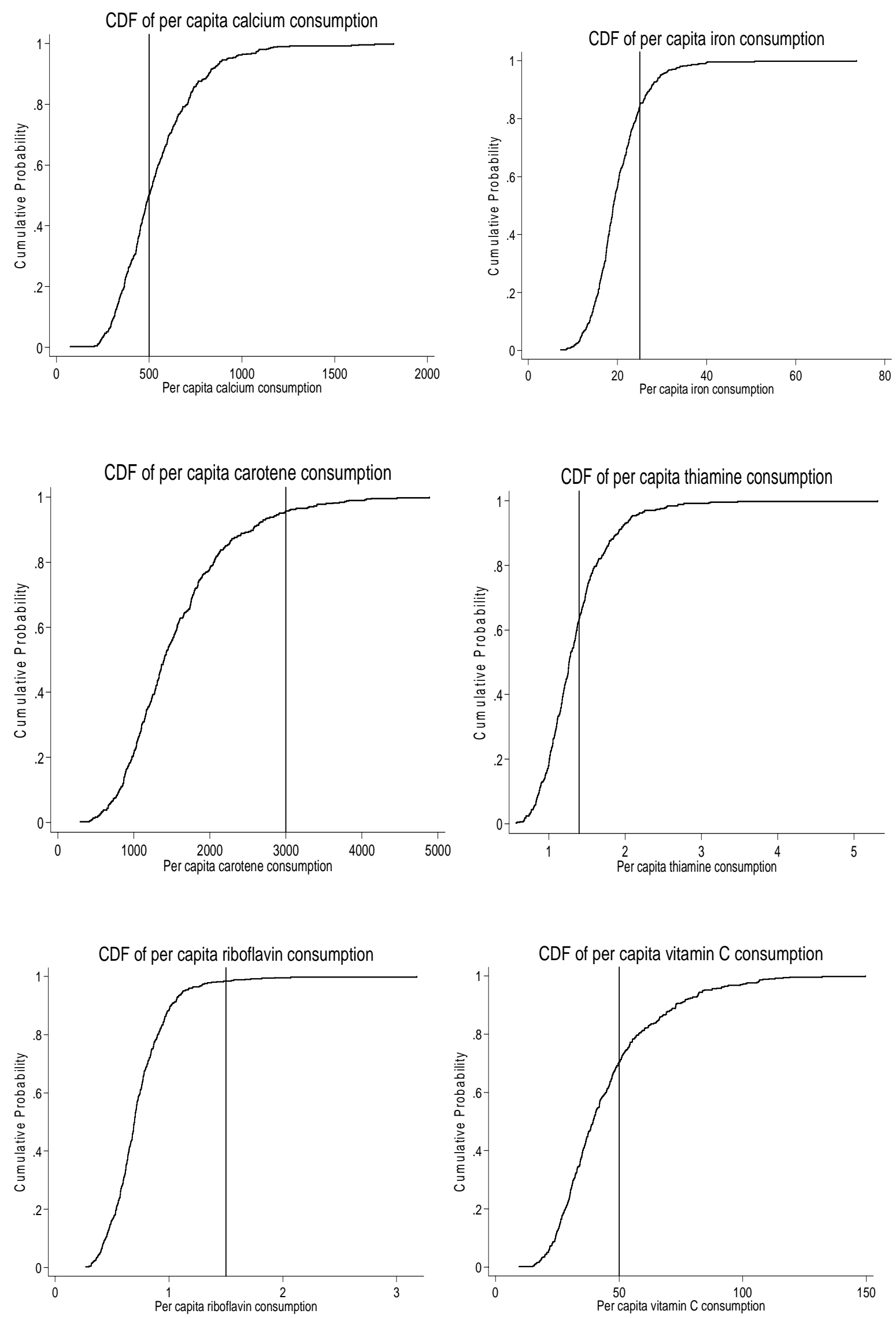


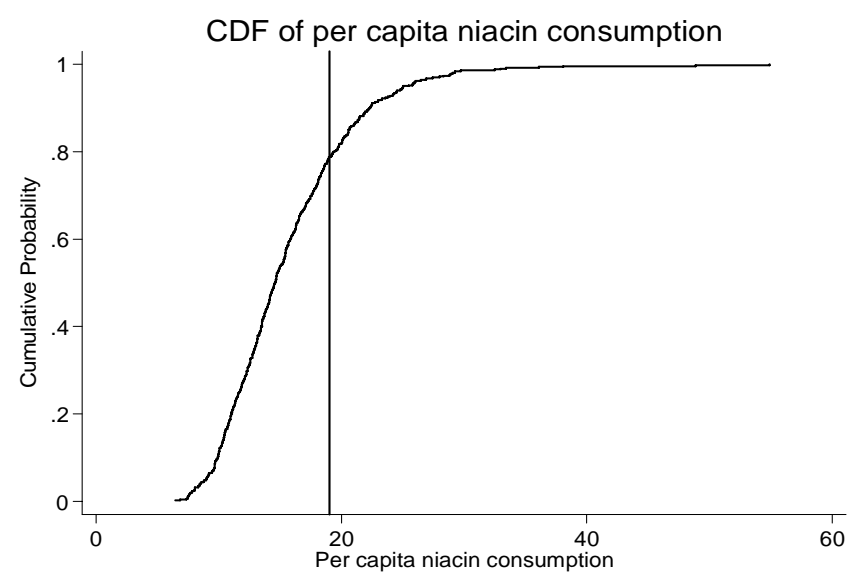

\section{Rajasthan}
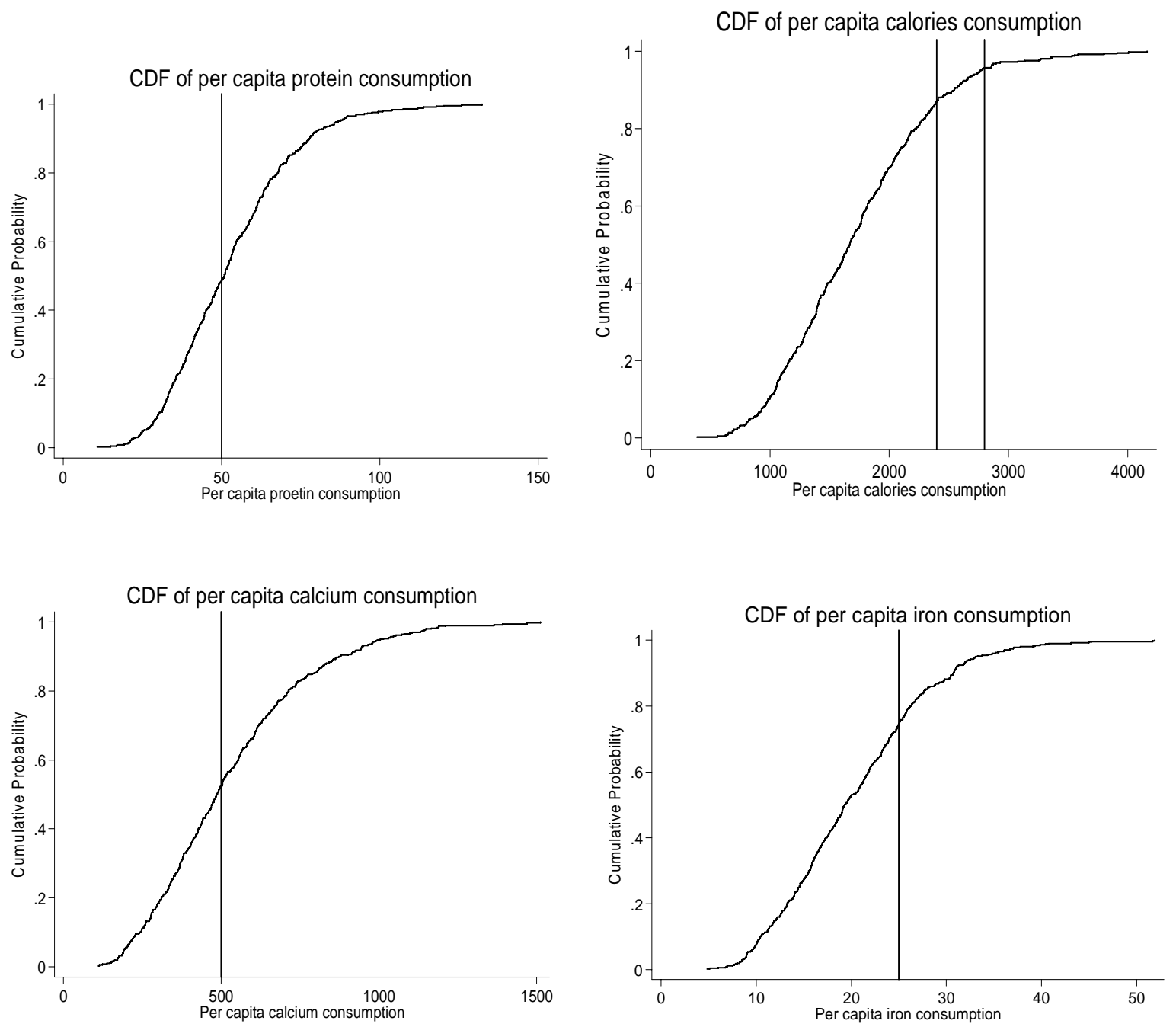

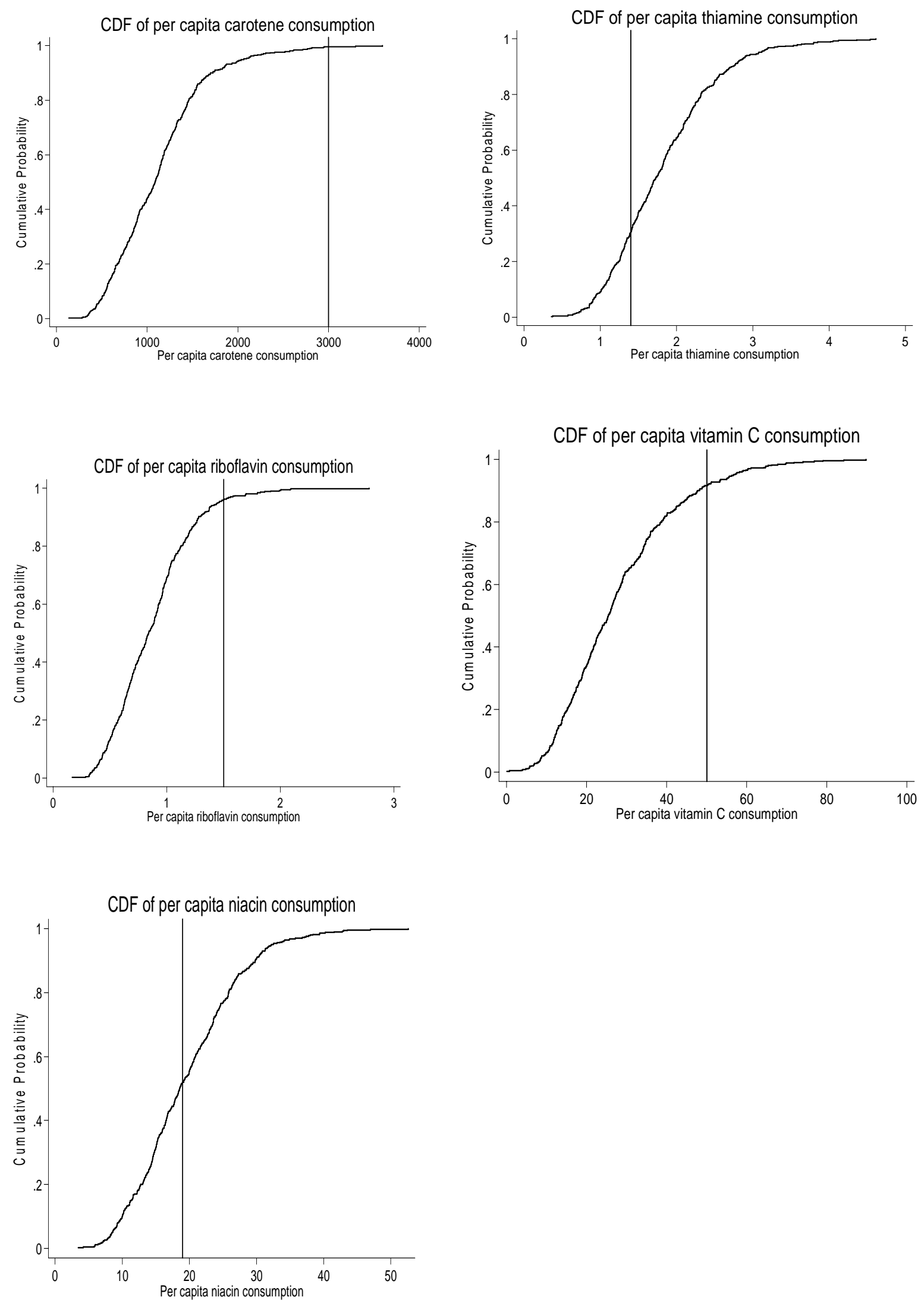

Note: Note that the CDFs involving calorie have two vertical lines signifying 2400 and 2800 as cut offs. All other vertical lines signify nutritional cut offs of different nutrients reported in Appendix I. 